\title{
Mineralogical and gemological characterization of emerald crystals from Paraná deposit, NE Brazil: a study of mineral chemistry, absorption and reflectance spectroscopy and thermal analysis
}

\author{
José Ferreira de Araújo Neto'* (D), Sandra de Brito Barreto' (D), Thais Andressa Carrino' (D), \\ Axel Müller ${ }^{2}$ (D), Lauro Cézar Montefalco de Lira Santos' ${ }^{1}$ (D)
}

\begin{abstract}
The Paraná deposit, located at Southwestern Rio Grande do Norte state, in Brazil, is one of the few emerald deposits found at Borborema Province. The mineralization occurs in phlogopite schists and actinolite-phlogopite schists associated with pegmatites and albitites within the Portalegre Shear Zone. Unlike other well-known Brazilian emerald deposits, the mineralogy of Paraná emeralds has remained poorly investigated for the last 40 years. In this study, we conducted mineralogical characterization of theses emeralds through gemological testing, mineral chemistry, absorption and reflectance spectroscopy, and thermal analysis. The Paraná emeralds are bluish-green colored, characterized by high refractive index, several two-phase fluid inclusions and mica is the main mineral inclusion. Electron probe microanalysis and laser ablation-inductively coupled plasma-mass spectrometry analyses detected the presence of $\mathrm{Fe}^{2+}(0.43-1.94 \mathrm{wt} . \% \mathrm{FeO})$ and $\mathrm{Cr}^{3+}$ (0.04-0.14 wt.\% $\left.\mathrm{Cr}_{2} \mathrm{O}_{3}\right)$ as the main chromophores replacing octahedral $\mathrm{Al}^{3+}$ in the crystal structure. In addition, substantial amounts of $\mathrm{MgO}(0.40-2.72 \mathrm{wt} . \%), \mathrm{Na}_{2} \mathrm{O}(0.50-1.81 \mathrm{wt} . \%)$, and $\mathrm{Cs}_{2} \mathrm{O}(0.07-0.44 \mathrm{wt} . \%)$ were also identified. The main causes for its coloration were attributed to $\mathrm{Cr}^{3+}$ absorption features in visible spectral range, which were corroborated by absorption and reflectance spectra. The presence of types I and $\mathrm{II}_{2} \mathrm{O}$ at channel-sites was recorded in Fourier-transform infrared spectra and demonstrated by dehydration processes observed in different thermal and thermogravimetric analyses.
\end{abstract}

KEYWORDS: Paraná emerald; mineralogy; gemology; geochemistry; spectroscopy.

\section{INTRODUCTION}

Emerald is a green gem variety of beryl $\left(\mathrm{Be}_{3} \mathrm{Al}_{2} \mathrm{Si}_{6} \mathrm{O}_{18}\right)$. Its coloration is due to amounts of $\mathrm{Cr}^{3+}, \mathrm{V}^{3+}$ or $\mathrm{Fe}$ replacing $\mathrm{Al}^{3+}$ at the $\mathrm{Y}$ site in the crystal structure, and it needs a specific geological environment to bring together such chromophore elements, which are commonly concentrated in mafic and ultramafic rocks, whereas Be is originated from Be-bearing pegmatites or, in some cases, brine fluids (Walton 2004).

The beryl structure was firstly reported by Bragg and West (1926) and it consists of an $\mathrm{Al}$ or $\mathrm{Y}$ site octahedrally coordinated by six oxygen atoms and Be and Si sites both tetrahedrally coordinated by four oxygen atoms. The arrangement of $\mathrm{SiO}_{4}$ tetrahedra forms stacked six-membered rings, which results in channel sites parallel to the crystallographic $\mathrm{c}$ axis.

${ }^{1}$ Departamento de Geologia, Universidade Federal de Pernambuco Recife (PE), Brazil. E-mails: araujoneto.geo@gmail.com; sandradebritobarreto@gmail.com; thais.carrino@gmail.com; lauromontefalco@gmail.com

${ }^{2}$ Natural History Museum - Oslo, Norway and Natural History Museum - London, United Kingdom. E-mail: a.b.muller@nhm.uio.no

${ }^{*}$ Corresponding author.

C) 2019 The autors. This is an open access article distributed under the terms of the Creative Commons license.
According to Wood and Nassau (1968), these channels can allow the entrance of alkali ions, such as $\mathrm{Na}, \mathrm{Cs}, \mathrm{Rb}$ and $\mathrm{K}$, as well as two types of water molecules: type $\mathrm{I}_{2} \mathrm{O}$, with no association to alkali ions, and type $\mathrm{II} \mathrm{H}_{2} \mathrm{O}$, coordinated with alkali ions. Type $\mathrm{II}_{2} \mathrm{O}$ can be singly ( $\mathrm{H}_{2} \mathrm{O}$ IIs) or doubly coordinated to an alkali ion ( $\mathrm{H}_{2} \mathrm{O}$ IId). The latter occurs in highly hydrated systems with two water molecules surrounding an alkali ion.

At the Borborema Province, Northeastern Brazil, emerald mineralizations are particularly uncommon. Punctual well known deposits are Tauá (Ceará state), which is recognized by low-quality emerald crystals (Schwarz 1987), and the recently discovered Fazenda Bonfim occurrence (Cavalcanti Neto and Barbosa 2007), within the Seridó Mobile Belt (Rio Grande do Norte state), which presents gem-quality crystals that were targeted for prospective activities and scientific research in the last decade (i.e., Scholz et al. 2010, Zwaan et al. 2012, Santiago et al. 2018).

The Paraná emerald deposit is located at the extreme Southwest of Rio Grande do Norte state and has been known since the 1980s. It has been recognized by considerable amounts of gem-quality crystals found in quartz and pegmatite veins hosted in biotite/phlogopite schists (Vasconcelos 1984, Moraes 1999). During such period, emeralds crystals were explored by local miners until almost exhaustion. Brief descriptions of the 
geological framework at the Paraná region were performed by the Geological Survey of Brazil in regional geological mapping (Medeiros 2008, Souza 2017), but the emerald mineralogical characterization remains uninvestigated. Recent mining activities in the region have been retaken by Mineração Limeira Comércio, Exportação e Importação Ltda, by opening a new commercial possibility for emerald from the Paraná deposit.

Since the Paraná emerald deposit is poorly known and may present important clues on the gemological-geological aspects of Borborema Province, this paper combines several analytical techniques, such as gemological study, mineral chemistry, absorption and reflectance spectroscopy, as well as thermal analysis to introduce and compose the mineralogical characterization of Paraná emerald crystals. Our aim is to investigate internal features and gemological properties, as well as the spectral signature and chemical composition of Paraná emerald, identifying chromophore elements responsible for the green coloration and the main substitutions at the $\mathrm{Y}$ and channel sites, generating suitable data that allow comparison with other emerald crystals found worldwide.

\section{GEOLOGICAL SETTING}

Paraná deposit is situated in the Rio Grande do Norte Sub-province of the Borborema Province (Fig. 1A). This sub-province is characterized by several major ductile shear zones that are probable Ediacaran-Cambrian in age (Brito Neves et al. 2000, Medeiros 2008, Viegas et al. 2014). Emerald mineralization occurs along the transcurrent Portalegre Shear Zone, in a discontinuous NE-SW trend with, at least, $20 \mathrm{~km}$ length (Moraes 1999). This regional-scale structure represents the contact between meta-granitoids of Jaguaretama Complex and both meta-plutonic and metavolcanossedimentary units of Caicó Complex (Medeiros 2008). The Paraná region is characterized by occurrences of phlogopite and actinolite-phlogopite schists that are part of the metavolcanossedimentary sequence of Caicó Complex (Fig. 1B), which also comprises spatially associated mylonites, gneisses, amphibolite, and quartzites.

The phlogopite and actinolite-phlogopite schists occur as vertical to subvertical lenses along mylonitic domains of Portalegre Shear Zone (Fig. 2A). They host several recrystallized veins and veinlets with granitic composition and aplitic to pegmatitic texture. These granitic bodies occur as boudins constituted mostly by quartz and/or feldspar and minor biotite (Fig. 2B). The emerald crystals have grown into the schists, as well as in these small granitic bodies or at the contact between both rocks (Fig. 2C).

Several granitic pegmatites have been reported within the Portalegre and Vieirópolis shear zones (Araújo Neto et al. 2018). At the Paraná deposit, centimeter- to meter-sized granitic pegmatite lenses and veins are found in association with the emerald host rocks. These pegmatites often present a simple

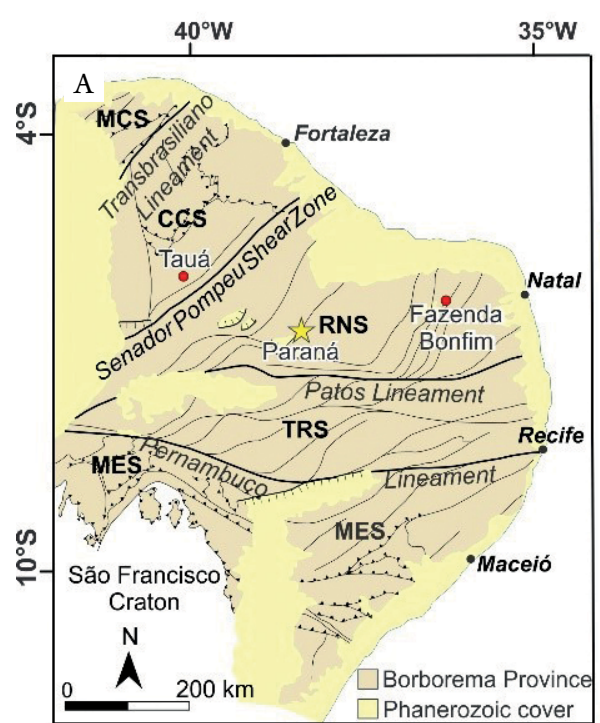

575000

590000

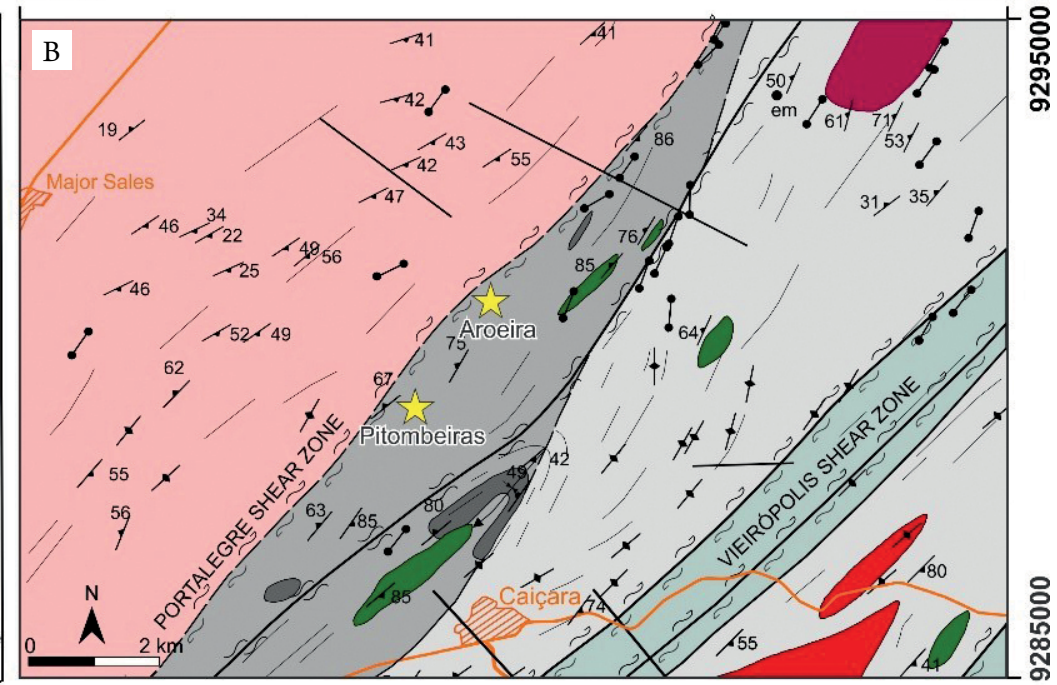

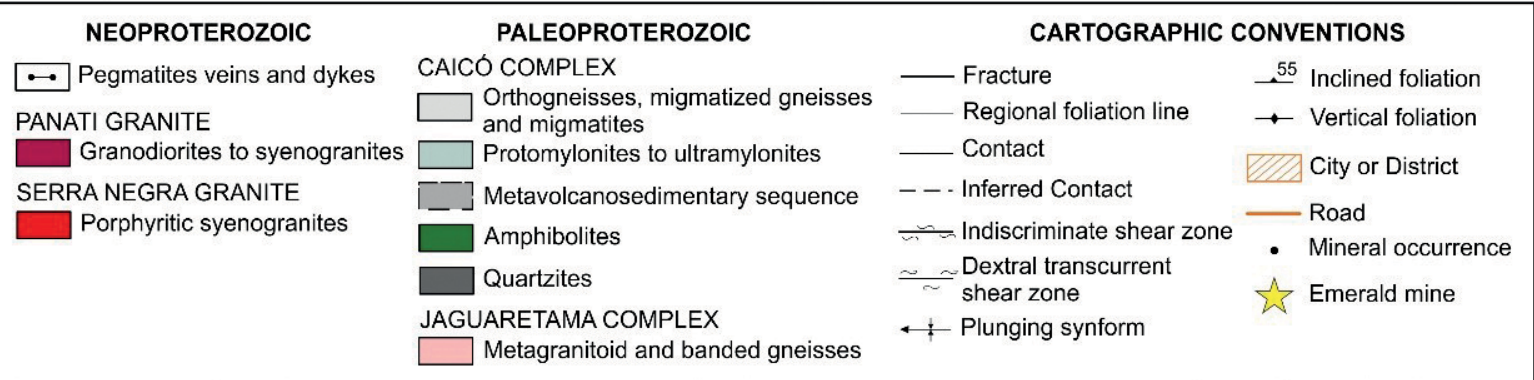

MCS: Médio Coreaú Sub-province; CCS: Ceará Central Sub-province; RNS: Rio Grande do Norte Sub-province; TRS: Transversal Sub-province; MES: Meridional Sub-province.

Figure 1. Regional geological setting of Paraná emerald deposit. (A) Main emerald deposits within the tectonic subdivisions of Borborema Province. Modified from Santos et al. (2014). (B) Geologic map of Paraná region with the localization of Aroeira and Pitombeiras mines. WGS 84 horizontal projected datum UTM zone 24S. Modified from Araújo Neto et al. (2018). 
composition that is made up of potassium feldspar with minor quartz and muscovite.

At least two main mines are recognized at the Paraná deposit: the Pitombeiras and the Aroeira mines. In these mine shafts, meter-sized dykes of sodium-rich plagioclase (albitite) can be found adjacent to the basement gneisses and host schists. These albitites occur as tabular sheared pegmatite bodies (Fig. 2D), which are mostly composed by albite but with minor light green muscovite.

\section{SAMPLING AND ANALYTICAL METHODS}

Emerald samples were collected in Pitombeiras and Aroeira mines or provided by Mineração Limeira Comércio Exportação e Importação Ltda. We examined three faceted emerald gemstones ranging from 0.98 to $3.55 \mathrm{ct}$, three polished parallel plates, three samples of pulverized emerald, and 20 thin sections made from emerald crystals and emerald-bearing rocks.

Standard gemological study was carried out at the Gemology Laboratory of Universidade Federal de Pernambuco (LABGEM - UFPE). A Schneider RF2 refractometer with polarizing filter and a refractive index fluid $(n=1.79)$ were employed to measure the refractive index and birefringence. Weight and specific gravity were obtained by a Shimadzu AUY220 hydrostatic digital analytical balance, with a sensibility of $0.1 \mathrm{mg}$.
Internal features were observed through transmitted light (TL), polarized light (PL), and dark field illumination (DFI) using a Schneider gemological microscope coupled with the Zeiss-Stemi (Stemi 2000-C) optical system and a Schneider horizontal oil-immersed gem microscope also coupled with the Zeiss-Stemi (Stemi 2000-C) optical system, both with maximum magnification of 50x. A calcite dichroscope was used for pleochroism observation. The Chelsea filter was employed for color variation test and short- and long-wave ultraviolet (UV) lamps were used to observe fluorescence.

Major and minor element chemical analysis was carried out on 15 emerald crystals (99 spots) in eight thin sections at the Electron Microprobe Laboratory of the Universidade de Brasília (LASON - UnB). The thin sections were previously carbon-coated in an Edwards Auto 306 vacuum chamber. Chemical data were obtained by JEOL JXA-8230 electron microprobe, equipped with a scanning electron microscope (SEM), five wavelength dispersive $\mathrm{X}$-ray spectrometers (WDS), and one energy dispersive X-ray spectrometer (EDS). The system was operated for standard silicate analysis, using LASON's internal standards for multi-standard calibration: albite $(\mathrm{Na})$, forsterite $(\mathrm{Mg})$, topaz $(\mathrm{F})$, microcline $(\mathrm{Al}, \mathrm{Si}$ and $\mathrm{K})$, andradite $(\mathrm{Ca}$ and $\mathrm{Fe})$, vanadinite $(\mathrm{Cl}$ and $\mathrm{V}), \mathrm{MnTiO}_{3}$ ( $\mathrm{Ti}$ and $\mathrm{Mn}), \mathrm{Cr}_{2} \mathrm{O}_{3}(\mathrm{Cr}), \mathrm{NiO}(\mathrm{Ni})$, and pollucite (Cs). The following parameters were used: acceleration voltage of $15 \mathrm{kV}$, with bean current of $10 \mathrm{nA}$, bean diameter of $1 \mu \mathrm{m}$, and a 10 -second
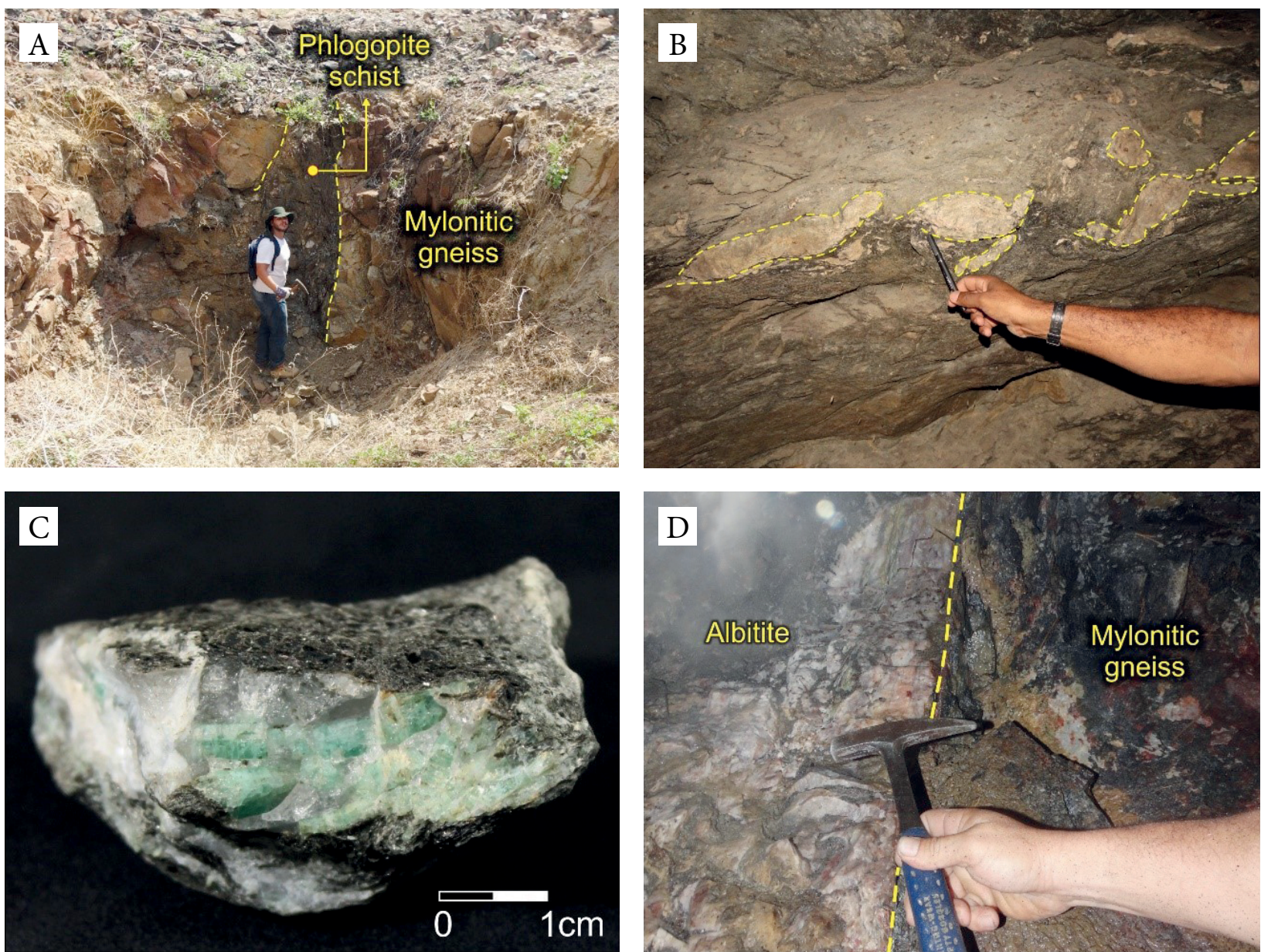

Figure 2. Geological features of Paraná emerald deposit. (A) Vertical contacts between phlogopite schist and mylonitic gneiss. (B) Quartz-feldspar boudins inserted in the phlogopite schist on a gallery wall at Pitombeiras mine. (C) Light-colored emerald prisms in a quartz vein hosted in the phlogopite schist. (D) Contact between albite pegmatite (albitite) and mylonitic gneiss at Pitombeiras mining front. 
count time for peak. Optical microscope images from CCD video camera and backscattered electron images were used for selecting analysis spots and avoiding mineral inclusions.

Minor and trace elements were determined by laser ablation-inductively coupled plasma-mass spectrometry (LA-ICP-MS) conducted in 12 thin sections of emerald crystals. The analysis was performed at the Geological Survey of Norway, using a double-focusing sector field mass spectrometer, model ELEMENT XR, from Thermo Scientific, which is combined with a NewWave UP193FX laser probe. The 193-nm laser had a repetition rate of $20 \mathrm{~Hz}$, a spot size of $75 \mu \mathrm{m}$, and an energy fluence of 5.5 to $6.5 \mathrm{~mJ} / \mathrm{cm}^{2}$ on the sample surface. A continuous raster ablation with laser speed of $15 \mu \mathrm{m} / \mathrm{s}$ on an area of approximately $300 \times 150 \mu \mathrm{m}$ was applied in the emerald crystals. The isotope ${ }^{29} \mathrm{Si}$ was used as internal standard, by applying Si concentration obtained through electron microprobe or stoichiometric concentration of $\mathrm{Si}$ in $\mathrm{Be}_{3} \mathrm{Al}_{2} \mathrm{SiO}_{6}$ for emerald crystals without microprobe chemical data. External multi-standard calibration was performed using the reference materials NIST SRM 610, 612, and 614 and 1830, BAM No.1 amorphous $\mathrm{SiO}_{2}$ glass from the Federal Institute for Material Research and Testing in Germany, the Qz-Tu synthetic pure quartz monocrystal provided by Andreas Kronz from the Geowissenschaftliches Zentrum Göttingen (GZG), Germany. Certified, recommended, and proposed values for these reference materials were taken from Jochum et al. (2011) and from the analysis certificates, where available. Each measurement comprised 15 scans of each isotope. An Arblank was run before each reference material and sample measurement to determine the background signal. The background was subtracted from the instrumental response of the reference material/ sample before normalization against the internal standard, in order to avoid instrumental drift effects. This was carried out to avoid memory effects between samples. A weighted least squares regression model, including several measurements of the six reference materials, was used to define the calibration curve for each element.

Visible-near infrared absorption spectra were obtained for three double-sided polished emerald plates using a PerkinElmer spectrophotometer, Lambda 35 model, at the Ionizing Radiation Metrology Laboratory of Universidade Federal de Pernambuco. The spectrophotometer operated in the $400-1,100 \mathrm{~nm}$ spectral range, with $4 \mathrm{~nm}$ slit, data interval of $1 \mathrm{~nm}$ and scanning speed of $120 \mathrm{~nm} / \mathrm{min}$. Short-wave and mid-wave infrared spectra of the same three samples were obtained at the Mineral Technology Laboratory of Universidade Federal de Pernambuco, using a Bruker Fourier-transform infrared (FT-IR) spectrometer, model Vertex 70 , operating in a range from 7,500 to $1,500 \mathrm{~cm}^{-1}$ with an $128 \mathrm{x}$ scanning and a resolution of $4 \mathrm{~cm}^{-1}$.

Reflectance spectroscopy was conducted in 10 rough and faceted emerald crystals, using FieldSpec $4^{\mathrm{TM}}$ Standard Resolution spectroradiometer (Analytical Spectral Devices) at the Institute of Geoscience of the Universidade Estadual de Campinas (UNICAMP). The spectroradiometer records spectra in 2,151 channels, with wavelengths ranging from 350 to 2,500 $\mathrm{nm}$ that comprise the visible to near infrared range (VNIR, 350-1,200 $\mathrm{nm}$ ) and the short-wave infrared range
(SWIR, 1,200-2,500 nm). The spectral resolution is $1.4 \mathrm{~nm}$ for the 350-1,000 nm range, and $1.1 \mathrm{~nm}$ for $1,001-2,500 \mathrm{~nm}$ (Malvern Panalytical 2018). A contact probe with internal light source and $\sim 20 \mathrm{~mm}$ spot size was used. Data were calibrated using a Spectralon ${ }^{\circledast}$ white plate. The samples were measured at least three times, and an average reflectance curve was calculated for each sample.

Differential thermal and thermal gravimetric analyses were performed simultaneously in three emerald powder samples at the Mineral Technology Laboratory of Universidade Federal de Pernambuco, using a Shimadzu thermal analyzer, DTG $60 \mathrm{H}$ model, with a heating rate of $10^{\circ} \mathrm{C} / \mathrm{min}$ and maximum temperature of $1,150^{\circ} \mathrm{C}$. The atmosphere used for the analyses was nitrogen $\left(\mathrm{N}_{2}\right)$. Calcined alumina was used as a reference material and an alumina cylindrical crucible was used at $0.5 \mathrm{~mm}$ diameter and $0.25 \mathrm{~mm}$ height.

\section{GEMOLOGICAL PROPERTIES}

Emerald crystals are translucid to transparent and occur as hexagonal prisms with irregular basal termination (Fig. 3A). They show green to bluish green colors, varying from weak to strong saturations (Fig. 3B). Crystals with strong color saturation present expressive greenish blue to yellowish green dichroism under the dichroscope and polarized light microscope (Fig. 3C). Growth and color zoning concentric to the $\mathrm{c}$ axis is evidenced in emerald plates parallel to the basal plane (Fig. 3D).

Refractive indexes measurements of the ordinary $\left(\mathrm{n}_{\mathrm{o}}=1.590\right)$ and extraordinary $\left(\mathrm{n}_{\mathrm{e}}=1.580-1.583\right)$ rays yield a birefringence from 0.007 to 0.010 . Average specific gravity is 2.74 , and the examined crystals are inert to short- and longwave UV radiation, besides they do not show a reaction under the Chelsea filter.

The dominant group of inclusions is the two-phase liquid-gas type fluid inclusions (Fig. 4A). Several inclusions exhibit a preferential orientation that corresponds to a crystallographic direction of the emerald crystal (possibly the $c$ axis), thus being considered primary inclusions contemporaneous with the crystal growth. The cavities containing fluid inclusions are parallel to fine growth tubes and have an irregular or rectangular shape. They usually occur as elongated rectangles with straight or cuneiform termination or as negative crystals (crystal-like cavities). Two-phase inclusions were also observed in partially healed fissures (Fig. 4B). These inclusions are considered pseudo-secondary because they are hosted in late-formed fissures, but still during crystal growth. The entangling of numerous fractures cracks and healing fissures confers a Jardin aspect to these emeralds (Fig. 4C), due to the resemblance of shrubs in a garden.

Few mineral solid inclusions were encountered. Brownish and greenish mica plates with hexagonal sub-idiomorphic to idiomorphic forms are the main mineral inclusions. These mica crystals occur parallel to the orientation of growth tubes; therefore, they are considered syngenetic solid inclusions (Fig. 4D).

Color-zoned emerald crystals, consisting of hexagonal, concentric growth zones vary from different shades of 
A
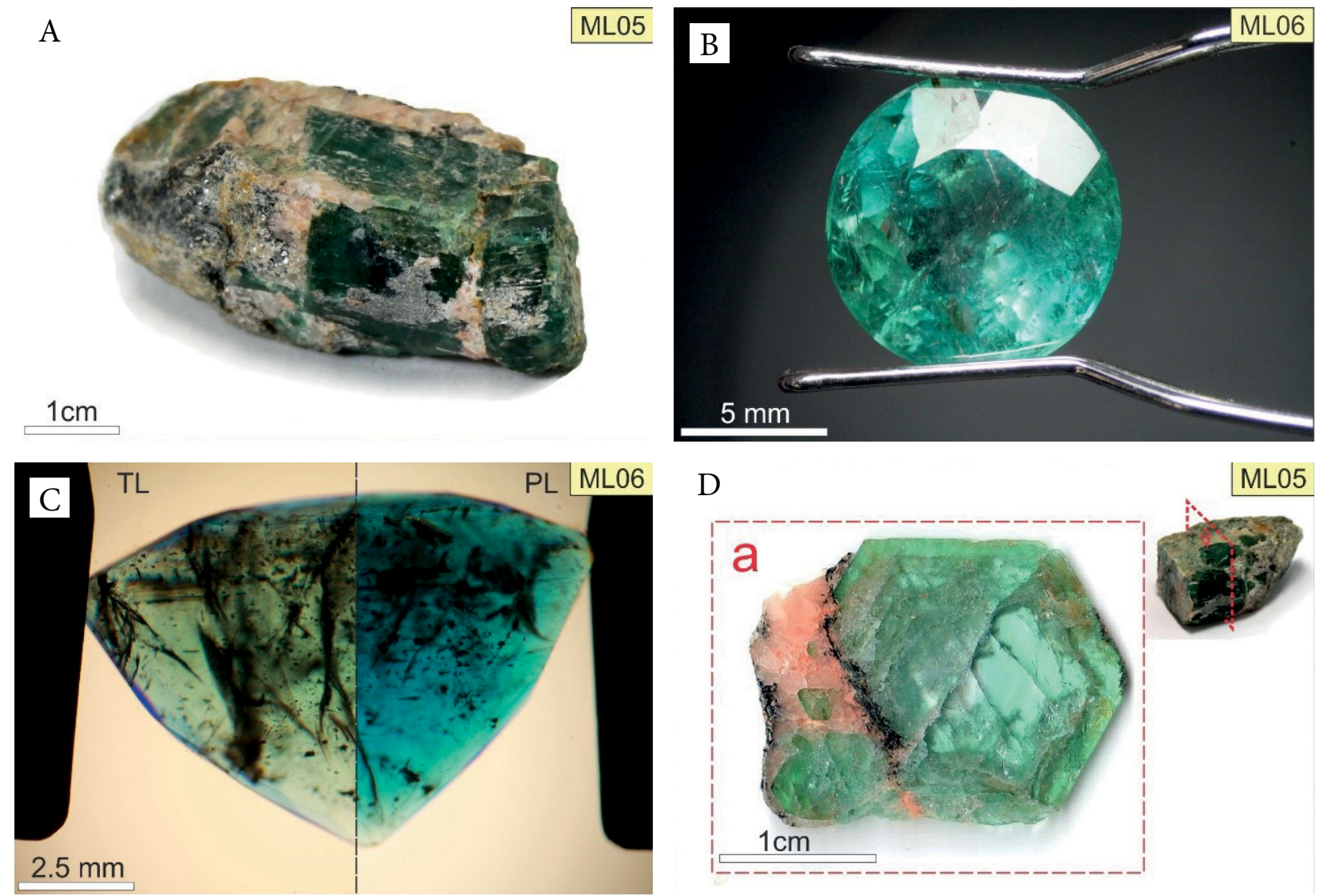

Figure 3. Emerald from Paraná deposit. (A) Rough emerald prism in quartz-feldspar matrix from Pitombeiras Mine. (B) Faceted bluish-green emerald from Aroeira Mine. (C) Dichroism in faceted emerald under transmitted light (TL) and polarized light (PL) in immersion horizontal microscope. (D) Emerald basal section with concentric color zoning and associated feldspar and phlogopite along fractures.
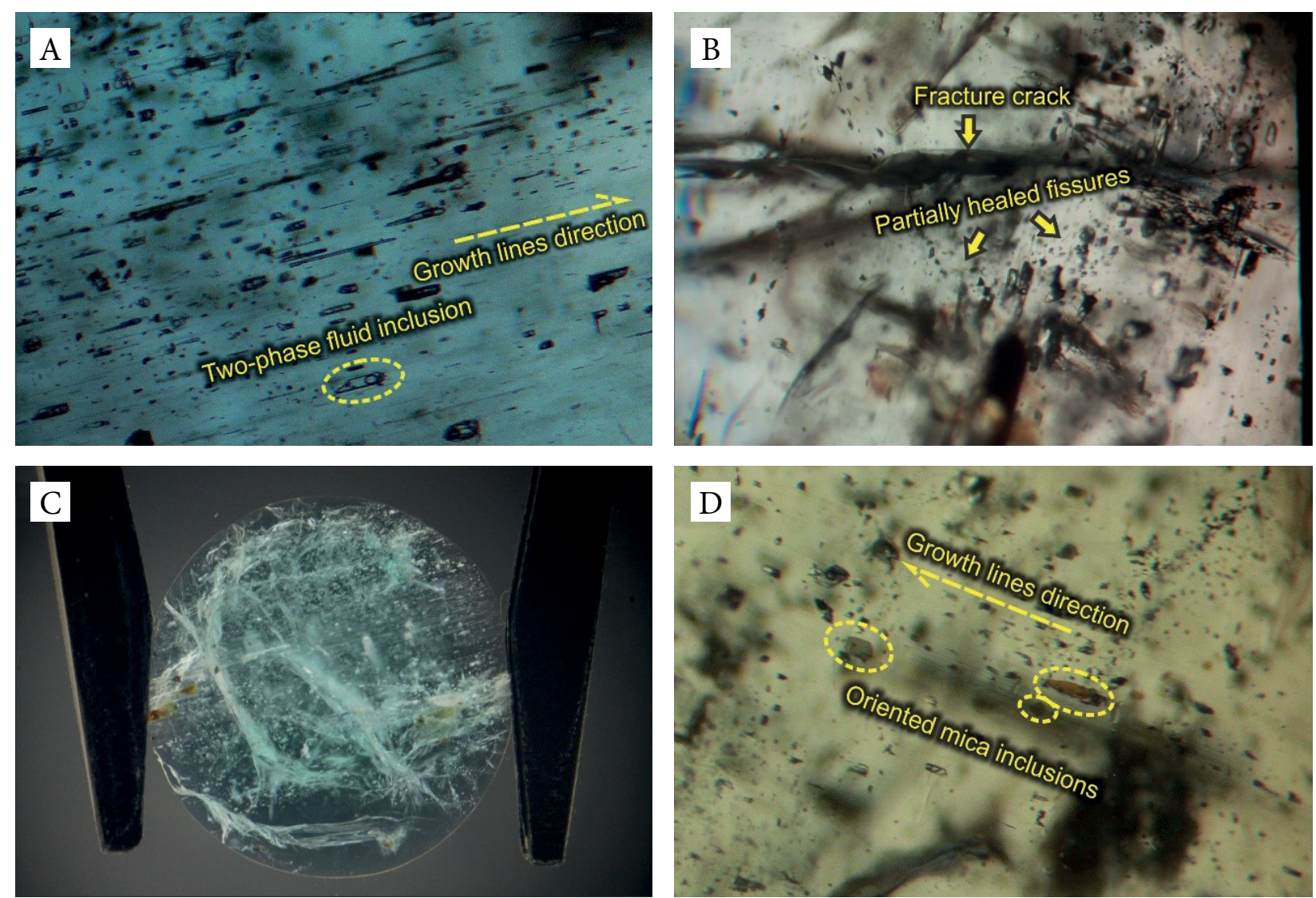

Figure 4. Interior features of a representative Paraná emerald crystal (ML06). (A) Two-phase fluid inclusions parallel to growth lines direction (50x PL). (B) Fluid inclusions in partially healed fissures (50x TL). (C) Jardin pattern generated by several fluid inclusions, cracks, and fissures (12.5x DFI). (D) Mica lamellae inclusions parallel to growth lines direction (50x PL). 
green to almost colorless. The crystals have two-phase fluid inclusions arranged along the color striations and concentrated in an intermediate zone, immediately external to the central colorless core (Fig. 5A). The distinct boundary between the colorless core and oscillatory zoned green overgrowth indicates a change in the crystallization environment. The oscillatory overgrowth may reflect extrinsic changes of the crystallization environment (P-T, tectonics?) or intrinsic diffusion-controlled growth, whereby the coloring agents become depleted due to fast crystal growth rate or enriched during slow growth.

Zones with high inclusion content were identified with SEM. Qualitative EDS analysis revealed inclusions of quartz, potassium feldspar, and sericitized plagioclase. They delimited two different zones in a hexagonal basal section. The presence of these two zones suggests that the Paraná emeralds have gone through at least two stages of crystal growth (Fig. 5B).

\section{CHEMICAL COMPOSITION}

Representative emerald electron microprobe chemical data are presented in Table 1. Paraná emeralds show moderate concentrations of $\mathrm{Fe}$ (average 0.94 wt.\% $\mathrm{FeO}$ ) and relatively low $\mathrm{Cr}$ (average $0.08 \mathrm{wt} . \% \mathrm{Cr}_{2} \mathrm{O}_{3}$ ) and $\mathrm{V}$ (average $0.02 \mathrm{wt} . \%$ $\mathrm{V}_{2} \mathrm{O}_{3}$ ). Intense bluish green samples contain these chromophore elements in concentrations, which are 1.4 to 2.6 times higher than those of crystals with less intense color (e.g. ML05 sample). The $\mathrm{FeO} /\left(\mathrm{Cr}_{2} \mathrm{O}_{3}+\mathrm{V}_{2} \mathrm{O}_{3}\right)$ ratio ranges from 5.0 to 21.6.

Concentrations of $\mathrm{Mg}$ are moderate to high (average $1.15 \mathrm{wt} . \% \mathrm{MgO}$ ), ranging from 0.40 to $2.72 \mathrm{wt} . \%$. Sodium and $\mathrm{Cs}$ are also present in relevant content of $1.00 \mathrm{wt} . \% \mathrm{Na}_{2} \mathrm{O}$ and 0.16 wt.\% $\mathrm{Cs}_{2} \mathrm{O}$. The $\mathrm{H}_{2} \mathrm{O}$ content was calculated through the empirical equation of Marshall et al. (2016), which established: $\mathrm{H}_{2} \mathrm{O}=0.5401 \ln \mathrm{Na}_{2} \mathrm{O}+2.1867$, leading to an average content of $2.15 \mathrm{wt} . \%$ for the Paraná emeralds.

TheLi, B, Mn, Ge, Rb, K, Ca, Sc, Ti, and Ga trace elements were detected by LA-ICP-MS (Tab. 2). Average K concentrations range from 210 to $1,811 \mathrm{ppm}$, while $\mathrm{Li}$ is found in relatively low concentrations of 86 to $381 \mathrm{ppm}$. Manganese, Ti,
$\mathrm{Ga}, \mathrm{Ge}$, and $\mathrm{B}$ are present in very low concentrations, averaging lower than $50 \mathrm{ppm}$. Germanium and B have specifically low concentrations of $<5 \mathrm{ppm}$.

The calculated values for atoms per formula unit (apfu) in Table 1 show deficiency of $\mathrm{Al}^{3+}$ at the octahedral coordinated $\mathrm{Y}$ structural site $(\mathrm{Al}<2 \mathrm{apfu})$, with mean values varying from 1.460 to $1.855 \mathrm{apfu}$. This $\mathrm{Al}^{3+}$ deficiency is commonly accompanied by accommodation of $\mathrm{Cr}, \mathrm{V}, \mathrm{Fe}, \mathrm{Mn}, \mathrm{Mg}, \mathrm{Ni}$, and $\mathrm{Ti}$. Figure $6 \mathrm{~A}$ shows the relationship between the $\mathrm{Al}$ content versus the sum of other Y-site cations, exhibiting a strong negative linear correlation, with a Pearson correlation coefficient (r) equal to -0.989. On the other hand, the substitution of $\mathrm{Al}^{3+}$ by bivalent cations (e.g., $\mathrm{Fe}^{2+}, \mathrm{Mg}^{2+}, \mathrm{Mn}^{2+}$, and $\mathrm{Ni}^{2+}$ ) at the $\mathrm{Y}$-site is associated with coupled substitutions of monovalent cations (e.g., $\mathrm{Na}^{+}, \mathrm{K}^{+}, \mathrm{Cs}^{+}$) in structural channels to obtain charge balance. As expected, Paraná emeralds have a strong positive linear correlation between the sum of Y-site bivalent cations versus the sum of monovalent cations of the structural channels, with $r$ equal to 0.982 (Fig. 6B). Samples that plot at the right side of the 1:1 straight line suggest that part of the analyzed Fe in emerald is present as $\mathrm{Fe}^{3+}$ (Groat et al. 2008).

\section{Chemical zoning}

EPMA element profiling was carried out on the ML05 crystal, in order to detect which coloring agents are responsible for the observed zoning. Figure 7 illustrates the chemical variation along the sampling profile.

The colorless core has a lower average $\mathrm{Al}_{2} \mathrm{O}_{3}$ content than the greenish margin (Fig. 7B), which allows an increased uptake of other Y-site cations. $\mathrm{MgO}$ is mainly higher in the core, suggesting that $\mathrm{Mg}^{2+}$ plays an important role as $\mathrm{Al}^{3+}$-substituent Y-site cation in the core zone. This is accompanied by the uptake of compensating monovalent cations in the structural channels, which is represented by the increase in $\mathrm{Na}_{2} \mathrm{O}$ and $\mathrm{K}_{2} \mathrm{O}$ concentrations (Fig. 7D). The $\mathrm{FeO}$ content shows an erratic behavior in the crystal core. While $\mathrm{V}_{2} \mathrm{O}_{3}$ behaves erratically across the entire crystal, the $\mathrm{Cr}_{2} \mathrm{O}_{3}$ content decreases considerably in this central colorless region (Fig. 7E). Thus, elevated
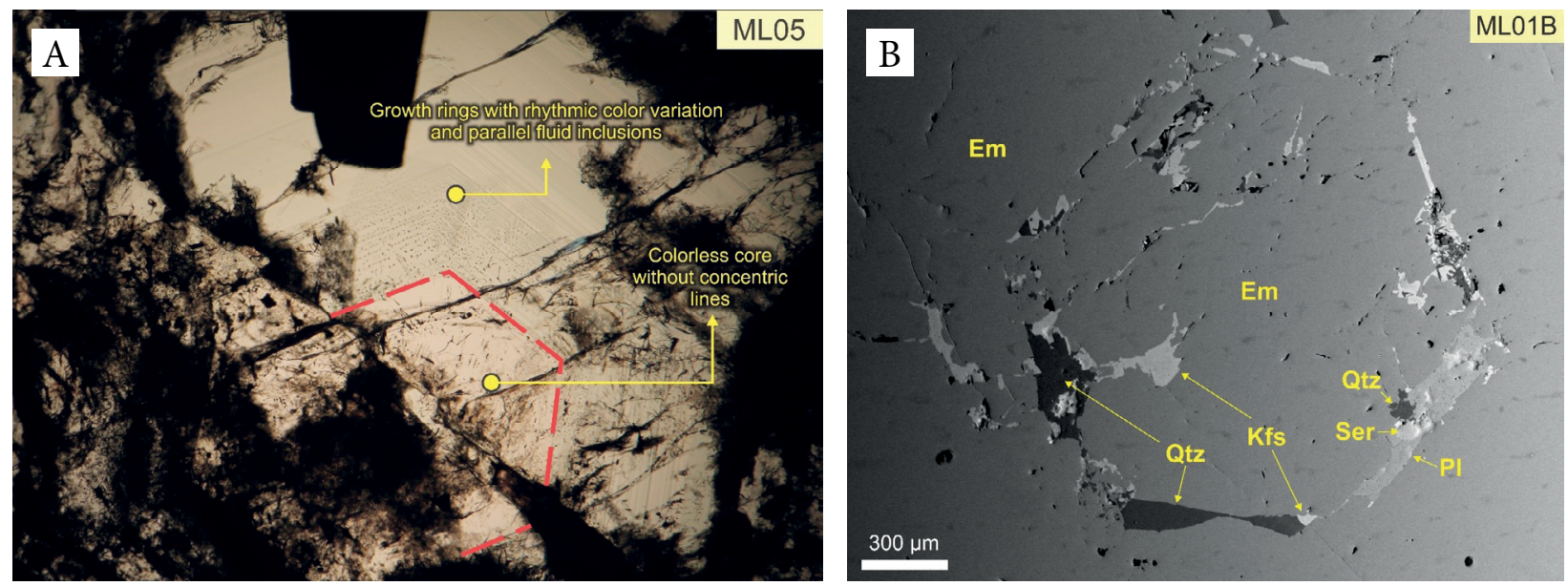

Figure 5. Zoned emerald crystals. (A) Oscillatory concentric color zoning. The red dashed line indicates the boundary between the colorless core and the outer, green growth zones (16x PL). (B) Backscattered electron image shows mineral inclusions of quartz (Qtz), K-feldspar $(\mathrm{Kfs})$, and sercitized (Ser) plagioclase $(\mathrm{Pl})$ delimiting two stages of crystal growth in an emerald crystal $(\mathrm{Em})$. 


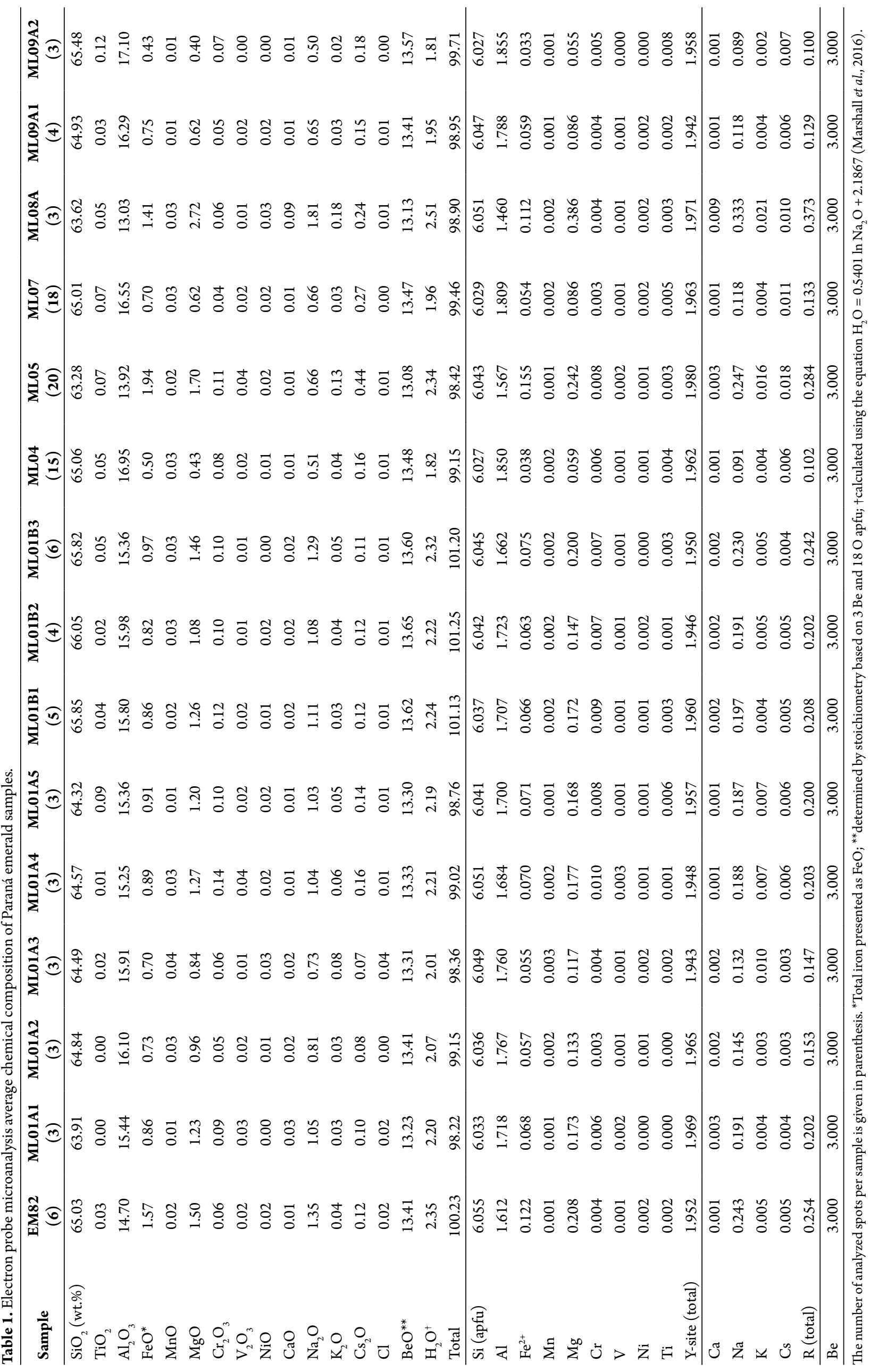


$\mathrm{Cr}^{3+}$ concentrations might be responsible for high green color intensities of Paraná emeralds.

\section{SPECTROSCOPY}

The absorption spectra of three double polished plates of emerald samples in the visible-near infrared range exhibit a broad absorption band with maximum absorption at $603-608 \mathrm{~nm}$, derived from electronic transitions in $\mathrm{Cr}^{3+}$ at the octahedral Y-site (transition ${ }^{4} \mathrm{~A}_{2} \rightarrow{ }^{4} \mathrm{~T}_{2}$, Wood and Nassau 1968). Subtle absorption features are present at 425-430, 682-684 and $637 \mathrm{~nm}$. They all indicate the presence of $\mathrm{Cr}^{3+}$ in the crystal structure.
A second broad absorption occurs in the range of 829-836 $\mathrm{nm}$ and it is attributed to the ${ }^{5} \mathrm{~T}_{2} \rightarrow{ }^{5} \mathrm{E}$ transition in $\mathrm{Fe}^{2+}$ at the octahedral Y-site (cf. Wood and Nassau 1968, Rondeau et al. 2008, Zwaan et al. 2012). Characteristic absorption VNIR spectra for Paraná emeralds are shown in Figure 8.

Spectra obtained by FT-IR spectroscopy applied on the same three emerald samples are characteristically for alkali-bearing emeralds (Fig. 9), with types I and $\mathrm{II}_{2} \mathrm{O}$ absorption features, besides features related to the presence of $\mathrm{CO}_{2}$ molecules ( $c f$. Wood and Nassau 1967, 1968, Schmetzer et al. 1997, Rondeau et al. 2008, Zwaan et al. 2012). The features centered at 7,098 and $5,275 \mathrm{~cm}^{-1}$ are

Table 2. Laser ablation-inductively coupled plasma-mass spectrometry (LA-ICP-MS) minor and trace element composition of Paraná emerald samples.

\begin{tabular}{lcccccccccccc}
\hline Sample & EM21 & MLO1A & ML01B & ML01C & ML02 & ML03 & ML04 $^{*}$ & MLO5* $^{*}$ & ML07* $^{*}$ & ML08 & ML09A & ML09B \\
\hline $\mathrm{Li}(\mathrm{ppm})$ & 125.87 & 195.83 & 183.74 & 217.32 & 160.98 & 98.79 & 381.17 & 171.02 & 366.58 & 86.54 & 325.22 & 353.15 \\
$\mathrm{~B}$ & 1.61 & 2.58 & 1.62 & 3.24 & 2.83 & 4.41 & 1.95 & 2.31 & 2.79 & 2.90 & 2.47 & 1.96 \\
$\mathrm{Ge}$ & 0.84 & 0.58 & 0.55 & 0.66 & 0.48 & 0.59 & 0.83 & 0.85 & 0.77 & 0.72 & 0.59 & 0.71 \\
$\mathrm{Rb}$ & 32.76 & 63.22 & 78.61 & 68.78 & 133.00 & 140.36 & 64.99 & 104.02 & 107.47 & 142.14 & 62.48 & 72.87 \\
$\mathrm{Cs}$ & $1,331.27$ & $1,553.11$ & $1,875.86$ & $1,619.03$ & $2,035.79$ & $5,110.79$ & $2,959.10$ & $5,595.66$ & $5,452.48$ & $5,970.31$ & $1,708.37$ & $2,466.92$ \\
$\mathrm{Na}$ & $3,900.05$ & $8,393.88$ & $9,146.13$ & $8,631.43$ & $13,807.80$ & $14,480.79$ & $4,015.59$ & $11,346.26$ & $5,510.30$ & $14,717.93$ & $4,814.85$ & $5,095.99$ \\
$\mathrm{Mg}$ & $3,309.87$ & $8,637.71$ & $9,501.11$ & $8,833.70$ & $16,705.98$ & $19,791.55$ & $2,971.31$ & $12,801.91$ & $4,787.15$ & $19,964.64$ & $3,690.90$ & $3,958.18$ \\
$\mathrm{P}$ & $<\mathrm{LOD}$ & $<\mathrm{LOD}$ & $<\mathrm{LOD}$ & $<\mathrm{LOD}$ & $<\mathrm{LOD}$ & $<\mathrm{LOD}$ & $<\mathrm{LOD}$ & $<\mathrm{LOD}$ & $<\mathrm{LOD}$ & $<\mathrm{LOD}$ & $<\mathrm{LOD}$ & $<\mathrm{LOD}$ \\
$\mathrm{K}$ & 250.23 & 441.88 & 527.90 & 470.46 & $1,415.91$ & $1,811.07$ & 254.03 & $1,350.40$ & 363.01 & $1,701.44$ & 209.93 & 213.00 \\
$\mathrm{Ca}$ & 23.75 & 69.84 & 76.60 & 75.27 & 342.88 & 493.74 & 23.16 & 229.71 & 20.63 & 570.72 & 21.88 & 24.89 \\
$\mathrm{Sc}$ & 23.53 & 73.99 & 71.51 & 82.22 & 140.23 & 85.82 & 23.96 & 341.94 & 66.88 & 121.91 & 34.33 & 35.99 \\
$\mathrm{Ti}$ & 10.03 & 3.88 & 3.08 & 3.48 & 3.78 & 44.31 & 10.08 & 58.75 & 14.60 & 73.47 & 5.17 & 9.49 \\
$\mathrm{~V}$ & 52.23 & 92.80 & 110.67 & 106.15 & 204.07 & 174.51 & 44.82 & 155.49 & 73.13 & 169.06 & 66.06 & 59.20 \\
$\mathrm{Cr}$ & 373.55 & 567.08 & 616.88 & 622.99 & 574.35 & 149.72 & 270.17 & 649.51 & 275.79 & 124.75 & 399.00 & 501.77 \\
$\mathrm{Mn}$ & 11.78 & 30.59 & 33.02 & 34.66 & 50.34 & 28.41 & 54.79 & 86.79 & 65.18 & 33.96 & 54.81 & 58.12 \\
$\mathrm{Fe}$ & $3,790.10$ & $5,909.42$ & $6,230.95$ & $6,629.29$ & $11,123.88$ & $12,953.17$ & $3,973.98$ & $14,608.05$ & $6,102.39$ & $12,891.85$ & $4,404.76$ & $4,701.20$ \\
$\mathrm{Ga}$ & 12.18 & 10.07 & 10.52 & 11.47 & 10.56 & 11.39 & 19.99 & 14.11 & 27.55 & 12.69 & 23.71 & 24.47 \\
\hline
\end{tabular}

Average of six analyses per sample at different spots; LOD: limit of detection; ${ }^{*}$ crystal also chemically analyzed by electron probe microanalysis.
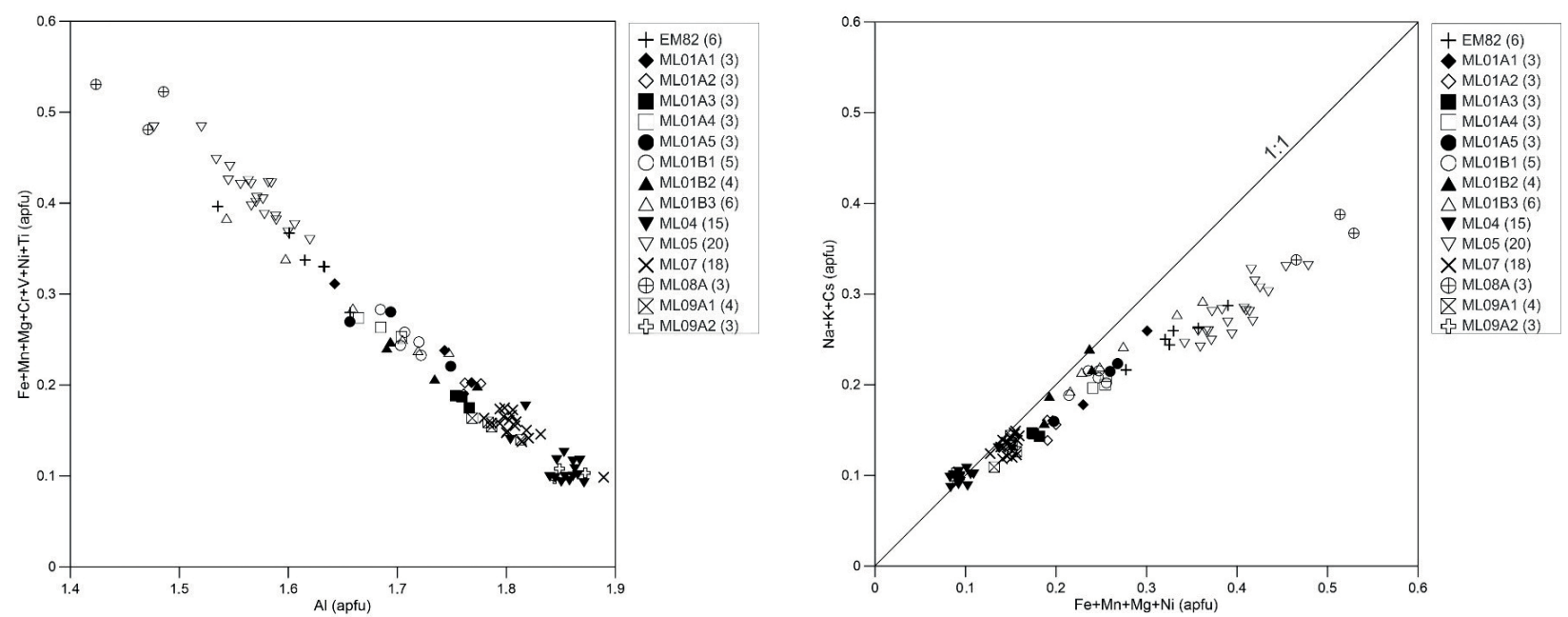

Figure 6. Correlation among different element concentrations for 99 analyzed spots on 15 emerald samples from Paraná. The number of analyzed spots per sample is given in parentheses. (A) Al versus the sum of other Y-site cations. (B) Bivalent Y-site cations versus monovalent channel-site cations. Diagrams after Groat et al. (2008). 

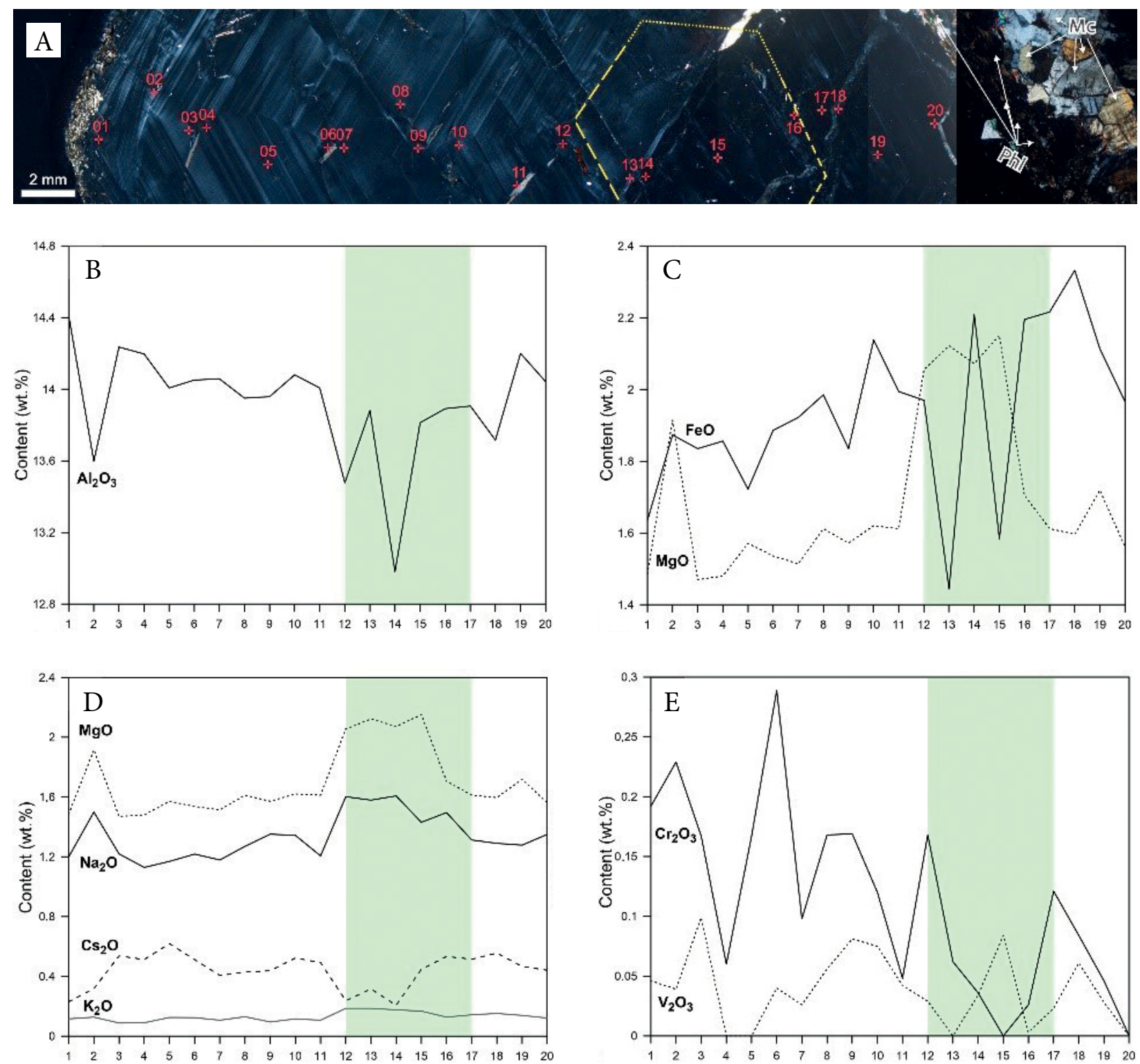

Mc: microcline; Phl: phlogopite.

Figure 7. Electron probe microanalysis analysis along a transversal profile in a color-zoned emerald crystal (sample ML05). (A) Basal section of sample ML05 showing the locations of the analytical EPMA spots. Crossed nicols. The diagrams show concentrations of $(\mathrm{B}) \mathrm{Al}_{2} \mathrm{O}_{3},(\mathrm{C}) \mathrm{FeO}$, $\mathrm{MgO},(\mathrm{D}) \mathrm{Na}_{2} \mathrm{O}, \mathrm{Cs}_{2} \mathrm{O}, \mathrm{K}_{2} \mathrm{O},(\mathrm{E}) \mathrm{Cr}_{2} \mathrm{O}_{3}$ and $\mathrm{V}_{2} \mathrm{O}_{3}$ along the profile. The green columns mark the analyses located in the colorless crystal core.
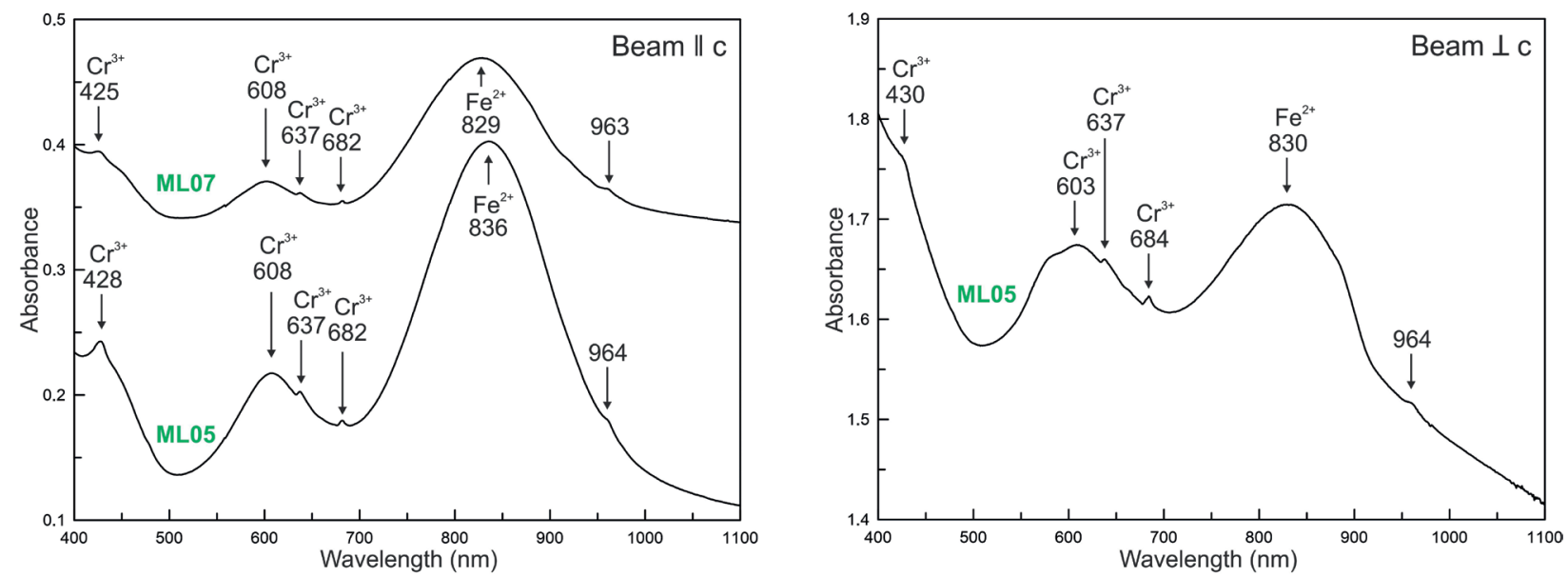

Figure 8. Visible and near infrared absorption spectra of Paraná emeralds. The spectra were obtained with incident beam parallel to the $\mathrm{c}$ axis (Beam $\| c)$ and perpendicular to the $c$ axis $($ Beam $\perp c)$. 
attributed to $\mathrm{H}_{2} \mathrm{O}$ II molecules (i.e., water molecules associated with alkali ions in the beryl structural channels; Wood and Nassau 1968). Subtle absorption features at 7,142, 5,448 and $5,100 \mathrm{~cm}^{-1}$ are associated with the presence of $\mathrm{H}_{2} \mathrm{O} \mathrm{I}$, and a large band between 4,000 and $3,350 \mathrm{~cm}^{-1}$ is related to the presence of both types of water molecules. The presence of $\mathrm{CO}_{2}$ is marked by a sharp absorption feature at $2,359 \mathrm{~cm}^{-1}$. Rondeau et al. (2008) also attribute the subtle absorption at the $2,376-2,378 \mathrm{~cm}^{-1}$ range to the $\mathrm{CO}_{2}$ molecule; therefore,
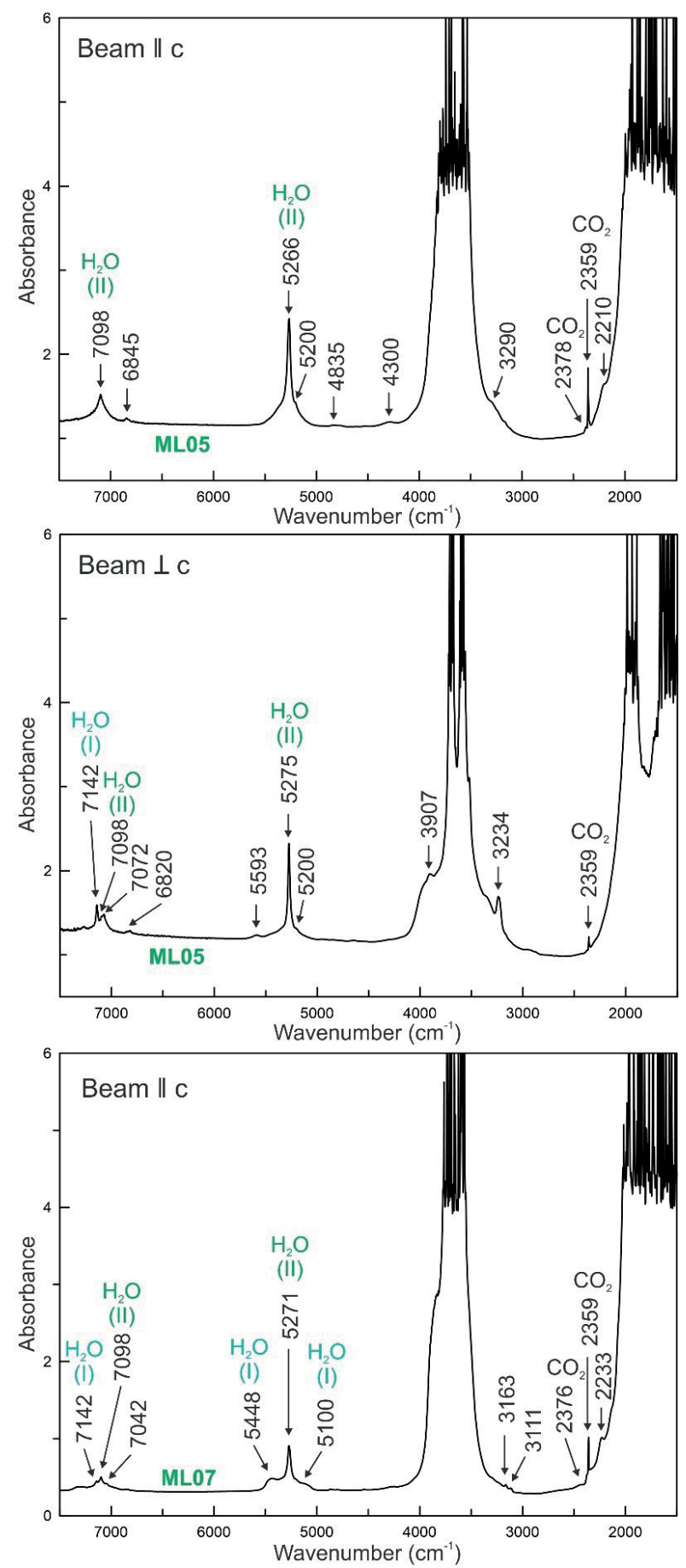

Figure 9. Fourier transform infrared (FTIR) absorption spectra of Paraná emeralds. The spectra were obtained with incident beam parallel to the $c$ axis (Beam $\| c$ ) and perpendicular to the $c$ axis $($ Beam $\perp$ c). these features may be derived from the isotopic effect of the combination of ${ }^{13} \mathrm{C}$ and ${ }^{18} \mathrm{O}$.

Reflectance spectroscopy was applied in three faceted emeralds, since it is a non-destructive method that does not need further sample preparation (Fig. 10). The Paraná emeralds show absorption features in the VNIR range at 428 and 611-629 nm related to electronic transitions in $\mathrm{Cr}^{3+}$, and a broad band centered at $848 \mathrm{~nm}$ derived from electronic transitions in $\mathrm{Fe}^{2+}$ at the octahedral Y-site (Wood and Nassau 1968, Rondeau et al. 2008, Zwaan et al. 2012). In the SWIR range, the emeralds show weak absorption features at $1,149 \mathrm{~nm}$, three sharp features between 1,375-1,460 $\mathrm{nm}$ (center at 1,410 nm) and other three sharp features between 1,785-2,022 nm (center at $1,894 \mathrm{~nm}$ ), all attributed to vibrational processes of types I and II water molecules (cf. Wood and Nassau 1967, 1968, Clark et al. 1990, Schmetzer et al. 1997, Rondeau et al. 2008). Four other absorption features centered at 2,072, 2,158, 2,205 and 2,329 $\mathrm{nm}$ were observed, but not identified.

\section{THERMAL ANALYSIS}

Differential thermal and thermal gravimetric analyses performed on three pulverized emerald samples demonstrate an endothermic reaction curve with maximum peak at $921-933^{\circ} \mathrm{C}$ (Fig. 11). At least two mass loss events by dehydration are registered at the temperatures of $300-500^{\circ} \mathrm{C}$ and $800-1,050^{\circ} \mathrm{C}$. The total water loss varies from 1.85 to $2.13 \mathrm{wt} . \%$ at $1,050^{\circ} \mathrm{C}$. Sample ML05 registered the higher water loss (2.13\%), which concurs with the high $\mathrm{H}_{2} \mathrm{O}$ content calculated by the empirical equation of Marshall et al. (2016).

The possible dehydration process starts with the loss of $\mathrm{H}_{2} \mathrm{O}$ I and/or $\mathrm{H}_{2} \mathrm{O}$ IId (doubly coordinated water), and then, at temperatures higher than $800^{\circ} \mathrm{C}$, there is the release of $\mathrm{H}_{2} \mathrm{O}$ IIs (singly coordinated water). This sequence is a result of the bond strength of each type of water molecule and the balance of forces at the structural channels, based on topology calculation and bond valence ( $c f$. Fukuda and Shinoda 2008, Fridrichová et al. 2016). Therefore, the mass loss at $300-550^{\circ} \mathrm{C}$ is attributed to the release of water types IId and/or I. Further mass loss at $800-1,050^{\circ} \mathrm{C}$ is associated with the loss of water type IIs.

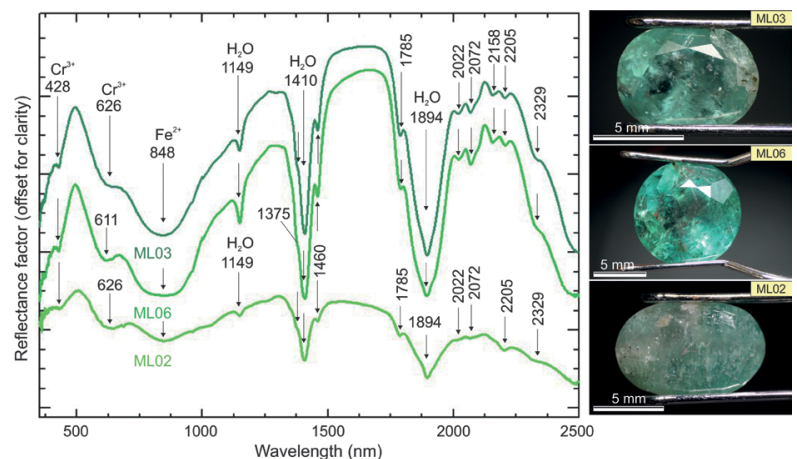

Figure 10. Staked reflectance spectra of faceted emerald samples. Average of five, four, and three spectral analyses for samples ML03, ML06 and ML02, respectively. 


\section{DISCUSSION}

Emerald mineralization in the Paraná region is a schist-type deposit controlled by a major shear zone. Chromium and Be sources are probably linked to spatially associated mafic rocks (metamorphosed into amphibolite) and Be-bearing pegmatites, respectively. Although beryl has not been found yet in meter-sized pegmatites lenses associated with the host rocks, emerald crystals can be commonly found in small pegmatite and aplite veins within the schist foliation. In addition, beryl-bearing pegmatites within regional shear zones are reported few kilometers east of the Paraná deposit (Barreto 1991). The presence of Na-rich plagioclase bodies associated with the emerald mineralization suggests metasomatic modification of granitic pegmatites through desilication (Giuliani et al. 1990,
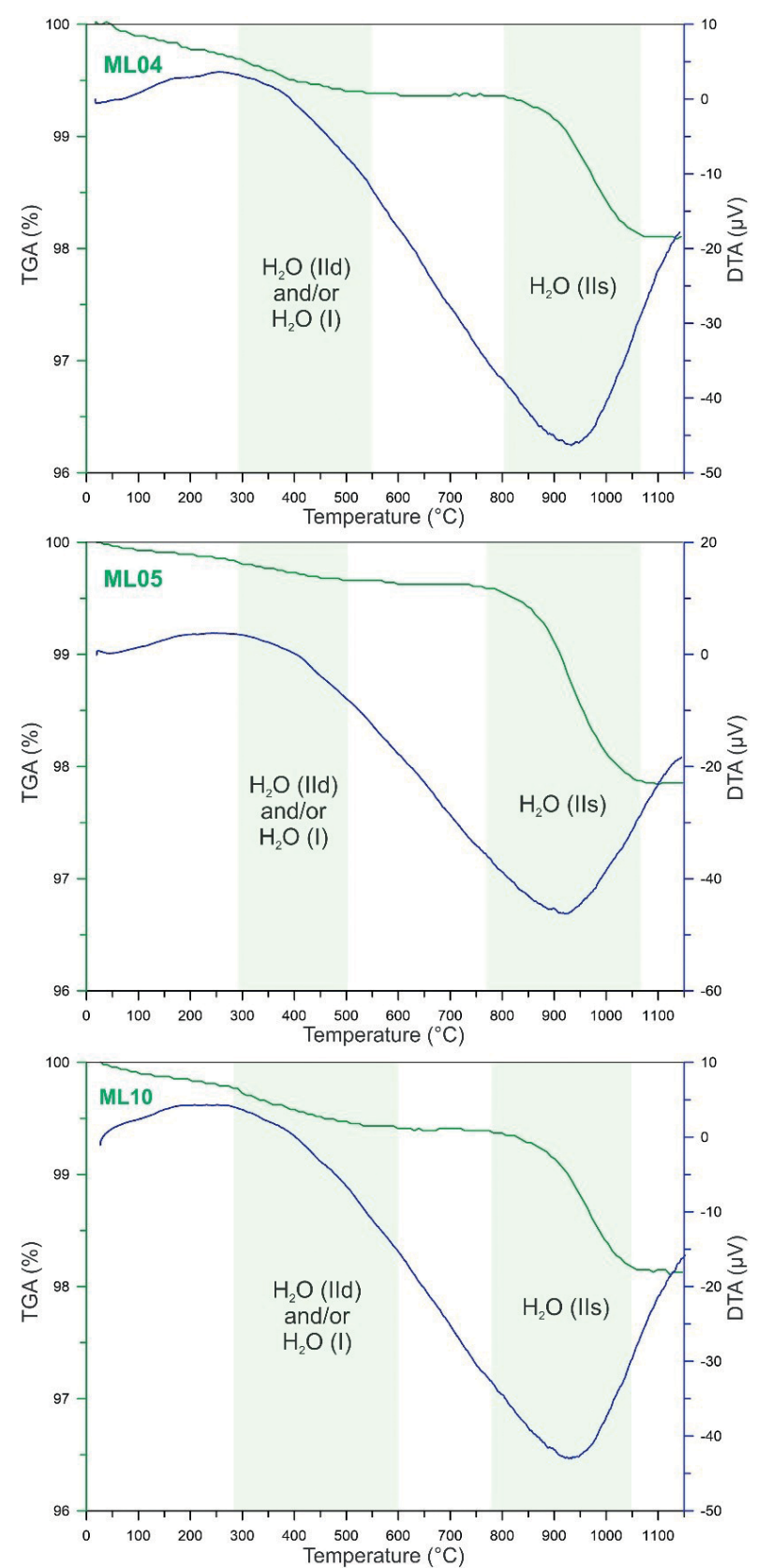

Figure 11. Thermogravimetric analysis/differential thermal analysis (TGA/DTA) curves of pulverized emerald samples. The green rectangles delimit the zones of the corresponding water molecule loss from the channel-sites.
Walton 2004). These so-called desilicated pegmatites or albitites are common to several Brazilian metasomatic emerald deposits, such as Carnaíba and Socotó - Bahia state (Giuliani et al. 1990) and Fazenda Bonfim — Rio Grande do Norte state (Zwaan et al. 2012).

The refractive indices for Paraná crystals are relatively high, but fall within the range expected for most natural emeralds, which is between 1.570 and 1.600 for the ordinary ray, and 1.564-1.593 for the extraordinary ray (Schwarz 1987). It is difficult to establish individual influences of the factors that have an increasing effect on refractive indices, but the presence of structural water and alkaline ions (specially $\mathrm{Na}$ and $\mathrm{Cs}$ ) and the high concentration of $\mathrm{Fe}$ and $\mathrm{Mg}$ are probably the main characteristics of Paraná emeralds. These high refractive indices, according to Zwaan et al. (2012), are common for schist-related emerald deposits.

The absence of reaction through Chelsea filter observation is typical for emeralds with high Fe content (e.g., South Africa and India emeralds; Webster 1975). Two-phase fluid inclusion is the main group of inclusions found in emerald crystals, but mineral inclusions such as mica (possibly phlogopite), feldspar and quartz were also identified. The non-appearance of pyrite inclusions can distinguish Paraná emeralds from Bahia ones, including those from Socotó and Carnaíba (cf. Schwarz 1987). Furthermore, the absence of amphibole inclusions is characteristic, since it is a common mineral inclusion in emeralds of other schist-related deposits of Brazil and around the globe (Schwarz 1987, 1998, Zwaan et al. 2005, 2012). Additionally, the color zoning accompanied by two-phase fluid inclusions concentration zones suggest an abrupt change in the physicochemical conditions of the environment at crystal growth (Schwarz 1987). Nevertheless, these internal features are very similar to those of Bonfim emeralds (Zwaan et al. 2012). Thus, additional chemical characterization should be performed for source mine identification.

According to the Schwarz (1987) empirical subdivision for $\mathrm{Cr}_{2} \mathrm{O}_{3}, \mathrm{FeO}, \mathrm{MgO}$ and $\mathrm{Na}_{2} \mathrm{O}$ concentration ranges in emeralds, the Paraná emerald presents low $\mathrm{Cr}$, medium to high $\mathrm{Fe}$, medium to low $\mathrm{Mg}$ and $\mathrm{Na}$. The main trivalent cations replacing $\mathrm{Al}^{3+}$ at the octahedral Y-site are $\mathrm{Cr}^{3+}, \mathrm{V}^{3+}$ and possibly $\mathrm{Fe}^{3+}$. Heterovalent substitution plays a major role at the octahedral Y-site, with the entry of $\mathrm{Fe}^{2+}$ and $\mathrm{Mg}^{2+}$ coupled with $\mathrm{Na}^{+}$ and other monovalent cations entrance at the channel sites. Figure 12A shows the relative concentration of the main substituents of octahedral Al for Paraná emerald and other deposits around the world. Magnesium is the main substituent for most of the samples, but Paraná emerald also contains Fe in similar proportions. In Figure 12B, the relative concentration of chromophore elements for Paraná emerald evidences that it is one of the highest Fe-rich emeralds among several other deposits. The comparison with other Brazilian emeralds is presented in Figures 13A and 13B, and the high Fe content allows the individualization of Paraná deposit from the others.

Zwaan et al. (2012) proposed several diagrams for discriminating Fazenda Bonfim deposit and other different schist-related emerald deposits, by plotting LA-ICP-MS chemical data. The Fazenda Bonfim deposit presents strong geological similarities with the 
Paraná deposit, including association with phlogopite schists and granitic intrusions, as well as being affected by transcurrent shear zones within the Rio Grande do Norte Sub-province (Zwaan et al. 2012, Santiago et al.2018). In the K-( $\mathrm{Li}+\mathrm{Cs})$-Rb ternary diagram, Paraná emeralds can be individualized by their higher amount of $\mathrm{Li}+\mathrm{Cs}$, especially for their high Cs content (Fig. 14).

Despite the low content of $\mathrm{Cr}^{3+}$, both absorption and reflectance spectra of the Paraná emeralds are typical of Cr-emeralds (Schmetzer et al. 1974, Zwaan 2006). They have absorption features at $428,608,637$, and $683 \mathrm{~nm}$ associated with the presence of $\mathrm{Cr}^{3+}$. Therefore, the absorption features derived from electronic transitions in $\mathrm{Cr}^{3+}$ and the weak absorption in the green range are responsible for its green coloration. This statement is in consonance with the decrease of $\mathrm{Cr}_{2} \mathrm{O}_{3}$ at the colorless core zones in zoned crystals (Fig. 7E). The presence of $\mathrm{Fe}^{2+}$ broad absorption feature at $\sim 830 \mathrm{~nm}$ does not influence its coloration, since it is situated outside the visible range (cf.Zwaan 2006). The spectra obtained for the ML05 sample cut
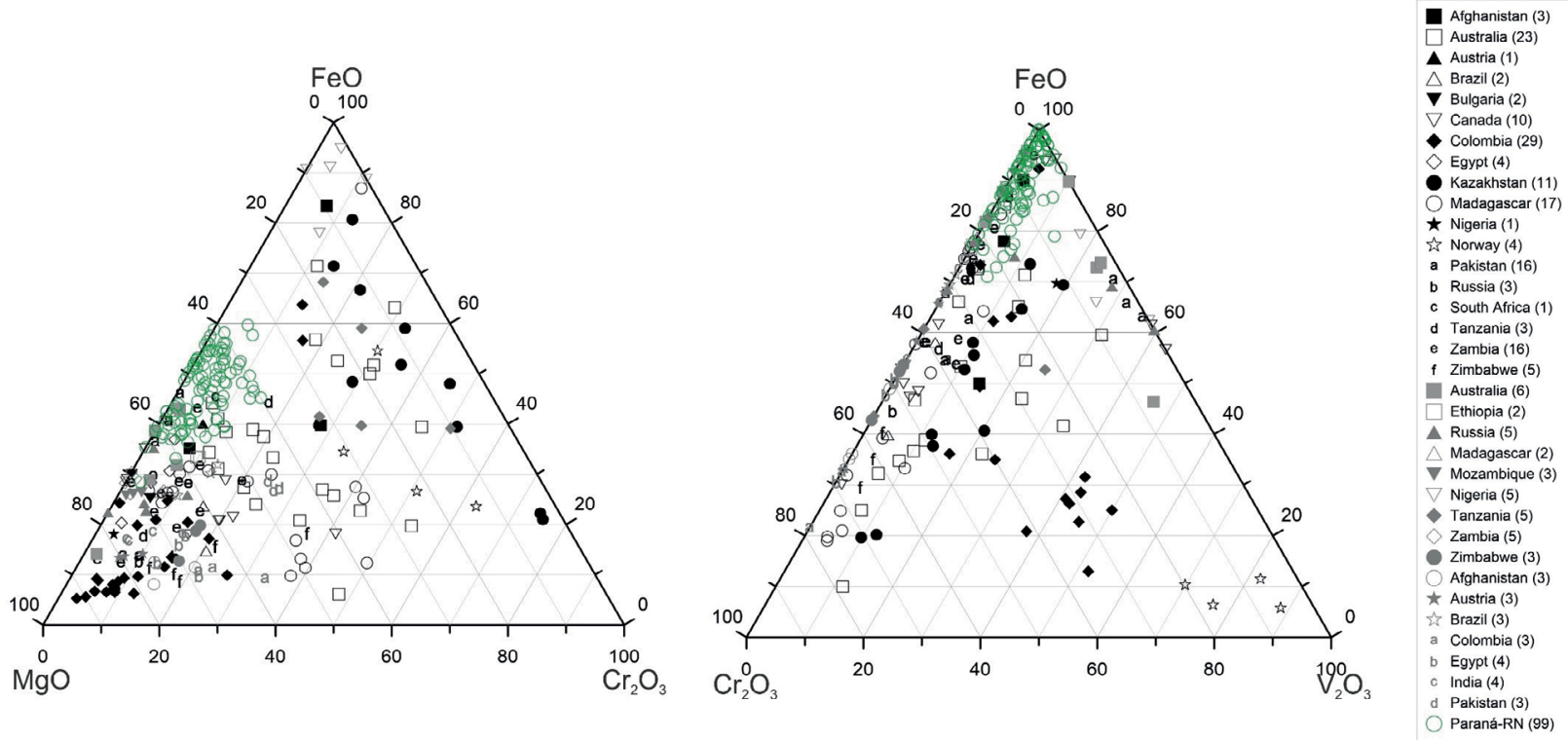

Figure 12. Ternary composition diagrams for Paraná emeralds and worldwide deposits. (A) Composition in terms of main $\mathrm{Y}$-site Al-substituents $\left(\mathrm{MgO}-\mathrm{FeO}-\mathrm{Cr}_{2} \mathrm{O}_{3}\right)$. (B) Composition in terms of main chromophore elements in emerald $\left(\mathrm{FeO}-\mathrm{Cr}_{2} \mathrm{O}_{3}-\mathrm{V}_{2} \mathrm{O}_{3}\right)$. Results shown for 210 analyses from literature and 99 analyses of Paraná emerald. The number of analyses per country is given in parenthesis. Symbols in black were compiled from Groat et al. (2008), which has as source of data: Kovaloff (1928), Zambonini and Caglioto (1928), Leitmeier (1937), Otero Muñoz and Barriga Villalba (1948), Simpson (1948), Gübelin (1958), Vlasov and Kutakova (1960), Martin (1962), Petrusenko et al. (1966), Beus and Mineev (1972), Garstone (1981), Hanni and Klein (1982), Graziani et al. (1983), Kozlowski et al. (1988), Hammarstrom (1989), Ottaway (1991), Schwarz (1991), Abdallah and Mohamed (1999), Gavrilenko and Pérez (1999), Alexandrov et al. (2001), Groat et al. (2002), Marshall et al. (2004), Vapnik et al. (2005, 2006), Zwaan et al. (2005), Gavrilenko et al. (2006) and Zwaan (2006). Symbols in grey were compiled from Aurisicchio et al. (2018). The diagrams are after Hammarstrom (1989).
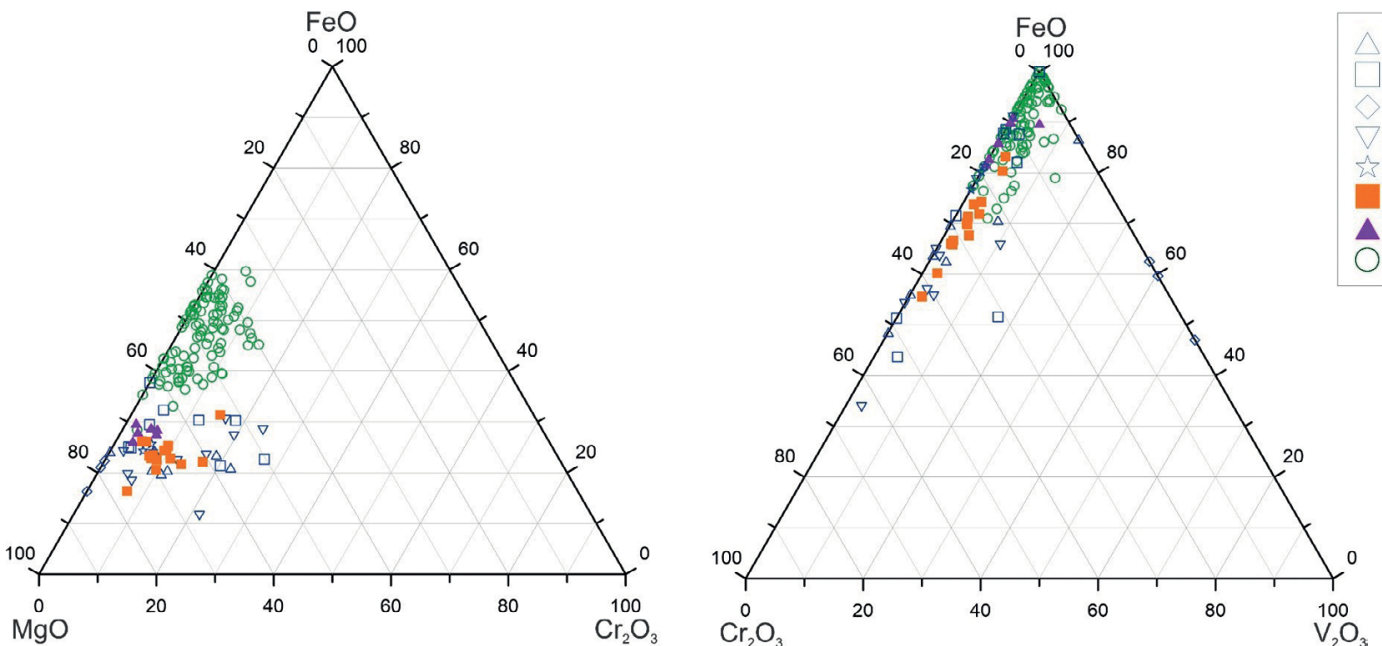

Carnaiba-BA (7)

tabira-MG (9)

Salininha-BA (3)

Santa Terezinha-GO (9)

Socotó-BA (3)

Fazenda Bonfim-RN (15)

Tauá-CE (6)

Paraná-RN (99)

Figure 13. Ternary composition diagrams for Brazilian emeralds. (A) Composition in terms of main $\mathrm{Y}$-site $\mathrm{Al}$-substituents $\left(\mathrm{MgO}_{\mathrm{O}}-\mathrm{FeO}_{-} \mathrm{Cr}_{2} \mathrm{O}_{3}\right)$. (B) Composition in terms of the main chromophore elements in emerald $\left(\mathrm{FeO}-\mathrm{Cr}_{2} \mathrm{O}_{3}-\mathrm{V}_{2} \mathrm{O}_{3}\right)$. Results shown for 52 analyses from literature and 99 of the Paraná emerald. The number of analyses per deposit is given in parenthesis. Fazenda Bonfim data compiled from Zwaan et al. (2012). Other chemical data compiled from Schwarz (1987), which has as source of data: Graziani and Lucchesi (1979), Hanni (1982), Hanni and Kerez (1983), Eidt and Schwarz (1987), Hanni et al. (1987) and Schwarz (1987). The diagrams are after Hammarstrom (1989). 
in different positions (parallel and perpendicular to the $\mathrm{c}$ axis) show variations in the maximum absorption centralization, as well as a variation of the relative absorbance values, which reflects the strong dichroism of Paraná emeralds (Fig. 3C).

FTIR spectra are consistent with alkali-rich emeralds (cf. Zwaan et al. 2012), with absorption features related to the presence of types I and II water (Fig. 8). The high content of sodium and the large water loss associated with type II water molecule suggest that the presence of type $\mathrm{II}_{2} \mathrm{O}$ in the structural channels is more expressive than type $\mathrm{I}_{2} \mathrm{O}$. Additionally, some $\mathrm{CO}_{2}$ molecules can also be expected, as evidenced by an absorption feature at $2,359 \mathrm{~cm}^{-1}$.

\section{CONCLUSIONS}

The Paraná emerald deposit, located at Rio Grande do Norte Sub-province of the Borborema Province, NE Brazil, is characterized by emerald-bearing granitic aplite and pegmatite veins within phlogopite and actinolite phlogopite schists associated with granite pegmatite bodies and desilicated pegmatites (albitites). These rocks form a mylonitic melange along the Portalegre Shear Zone. Interaction between such rocks at high temperature shearing most certainly allowed the mobilization of $\mathrm{Be}$ and chromophore elements, such as $\mathrm{Cr}, \mathrm{Fe}$ and $\mathrm{V}$ to form emerald.

Our study has shown that Paraná emeralds have a main bluish green color, although they are typically dichroic, varying from

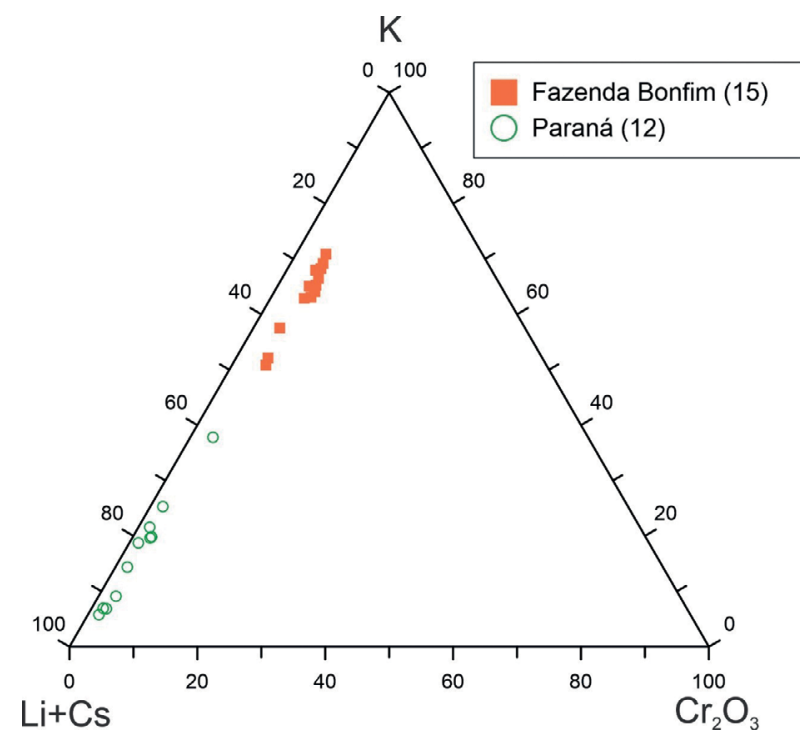

Figure 14. Ternary $\mathrm{K}-(\mathrm{Li}+\mathrm{Cs})-\mathrm{Rb}$ diagram for emeralds from Rio Grande do Norte sub-province. Average values in ppm obtained by laser ablation-inductively coupled plasma-mass spectrometry (LA-ICP-MS) for 12 samples from Paraná and 15 from Fazenda Bonfim. Data from Fazenda Bonfim compiled from Zwaan et al. (2012). Diagram after Zwaan et al. (2012). greenish blue to yellowish green. These crystals are colored mostly by $\mathrm{Cr}$, as evidenced by its characteristic absorption spectra and color zoning chemistry. However, due to its elevated Fe content, they exhibit broad absorption features at $\sim 830 \mathrm{~nm}$ and do not show reaction through Chelsea filter, which can be a diagnostic criterion to distinguish Paraná emeralds from several other schist-related deposits. Additionally, the high refractive indices, the presence of numerous two-phase fluid inclusions and partially healed fissures, and the absence of pyrite and amphibole as mineral inclusions can also be used as criteria for distinction from other Brazilian emeralds, such as those from Santa Terezinha (GO), Carnaíba (BA), Socotó (BA), Itabira (MG), and Tauá (CE).

When comparing our results with available data from Fazenda Bonfim emerald deposit, also located in Rio Grande do Norte Sub-province, there is some overlap when it comes to geological setting and internal features, but one can be easily differentiated from the other by its chemical composition. The Paraná emeralds show higher FeO content and lower $\mathrm{Cr}_{2} \mathrm{O}_{3}$. The alkali concentration can also be used for discriminating purposes, especially due to the elevated Cs content in Paraná emeralds, although spectroscopically they both show characteristics for alkali emeralds with strong absorption features related to the presence of type II water.

Future research at the Paraná deposit could focus on structural analysis, whole-rock/mineral geochemistry and isotope geology aiming to define mineralization controls and evolution, contributing to better understand the Borborema Province metallogenetic scenario.

\section{ACKNOWLEDGMENTS}

The authors are grateful to Mr. Luis Amorim and all the crew of Mineração Limeira Comércio, Exportação e Importação for providing support to our research in field studies and for supplying emerald samples. We thank Coordenação de Aperfeiçoamento de Pessoal de Nível Superior (CAPES) for the scholarship granted to José Ferreira de Araújo Neto. We would like to express our gratitude to Professor Dr. Nilson Botelho (Universidade de Brasília, Brazil) for the EPMA facilities. We thank Professor Dr. Lee Groat (University of British Columbia, Canada) for his assistance with emerald chemical data. We also thank Professor Dr. Pedro Guzzo and Fania Mateus (Universidade Federal de Pernambuco, Brazil) for spectroscopic and thermic analysis facilities. The reflectance spectroscopy was done in the Geoscience Institute of UNICAMP thanks to Professor Dr. Carlos de Souza Filho, Dr. Rebecca Scafutto, and Dr. Rosa Pabón. We appreciate Igor Souza and Glenda Santos of the Gemological Laboratory of the Universidade Federal de Pernambuco for their general assistance with this research.

\section{ARTICLE INFORMATION}

Manuscript ID: 20190014. Received on: 02/25/2019. Approved on: 06/19/2019.

Author J. N. wrote the first draft of the manuscript, prepared Figures 1 to 14 and produced Tables 1 and 2; author S. B. provided support and advisement regarding mineral chemistry, aided the field studies and gemological testing, improved the text through corrections and suggestions; author T. C. performed reflectance spectroscopy in emerald samples, aided the spectral interpretations, revised and improved the manuscript; author A. M. provided LA-ICP-MS data for emerald samples, revised and improved the manuscript; and author L. S. aided in field studies and geological characterization, revised, and improved the manuscript.

Competing interests: The authors declare no competing interests. 
Braz. J. Geol. (2019), 49(3): e20190014

\section{REFERENCES}

Abdalla H.M., Mohamed F.H. 1999. Mineralogical and geochemical investigation of emerald and beryl mineralisation, Pan-African Belt of Egypt: genetic and exploration aspects. Journal of African Earth Sciences, 28(3):581-598. https://doi.org/10.1016/S0899-5362(99)00033-0

Alexandrov P., Giuliani G., Zimmermann J.L. 2001. Mineralogy, age and fluid geochemistry of the Rila Emerald deposits, Bulgaria. Economic Geology, 96(6):1469-1476. https://doi.org/10.2113/gsecongeo.96.6.1469

Araújo Neto J.F., Lira Santos G., Souza I.M.B.A., Barreto S.B., Santos L.C.M.L., Bezerra J.P.S., Carrino T.A. 2018. Integration of remote sensing, airborne geophysics and structural analysis to geological mapping: a case study of the Vieirópolis region, Borborema Province, NE Brazil. Geologia USP. Série Científica, 18(3):89-103. https://doi.org/10.11606/issn.23169095.v18-140834

Aurisicchio C., Conte A.M., Medeghini L., Ottolini L., De Vito C. 2018. Major and trace element geochemistry of emerald from several deposits: Implications for genetic models and classification schemes. Ore Geology Reviews, 94:351-366. http://dx.doi.org/10.1016/j.oregeorev.2018.02.001

Barreto S.B. 1991. Caracterização químico-mineralógica dos berilos de Tenente Ananias - RN. MS Dissertation, Instituto de Geociências, Universidade Federal de Pernambuco, Recife, 219 p.

Beus A.A., Mineev D.A. 1972. Some Geological and Geochemical Features of the Muzo-Coscuez Emerald Zone, Cordillera Oriental, Colombia. Empresa Colombiana de Minas, $55 \mathrm{p}$.

Bragg W.L., West J. 1926. The structure of beryl, Be3Al2Si6O18. Proceedings of the Royal Society of London, 111:691-714.

Brito Neves B.B., Santos E.J., Van Schmus W.R. 2000. Tectonic History of the Borborema Province. In: Cordani U.G., Milani E.J., Tomaz Filho A., Campos D.A. (eds.), Tectonic Evolution of South America. 31st International Geological Congress. Rio de Janeiro, p. 151-182.

Cavalcanti Neto M.T.O., Barbosa R.V.N. 2007. As esmeraldas de Lajes, Caiçara do Rio dos Ventos e São Tomé/RN. Holos, 2:92-104. https://doi. org/10.15628/holos.2007.103

Clark R.N., King T.V.V., Klejwa M., Swayze G.A., Vergo N. 1990. High spectral resolution reflectance spectroscopy of minerals. Journal of Geophysical Research, 95(B8):12653-12680. https://doi.org/10.1029/ JB095iB08p12653

Eidt T., Schwarz D. 1987. Die Smaragde von Carnaíba, Bahia, Brasilien; Vorkommen und Charakteristika. Zeitschrift der Deutsche Gemmologische Gesellschaft, 36:3-4.

Fridrichová J., Bacik P., Bizovská V., Libowitzky E., Škoda R., Uher P., Ozdín D., Števko M. 2016. Spectroscopic and bond-topological investigation of interstitial volatiles in beryl from Slovakia. Physics and Chemistry of Minerals, 43(6):419-437. https://doi.org/10.1007/s00269-016-0806-9

Fukuda J., Shinoda K. 2008. Coordination of water molecules with $\mathrm{Na}+$ cations in a beryl channel as determined by polarized IR spectroscopy. Physics and Chemistry of Minerals, 35(6):347-357. http://dx.doi. org/10.1007/s00269-008-0228-4

Garstone J.D. 1981. The geological setting and origin of emeralds from Menzies, Western Australia. Journal of the Royal Society of Western Australia, 64:53-64.

Gavrilenko E.V., Pérez B.C. 1999. Characterisation of emeralds from the Delbegetey deposit, Kazakhstan. In: Stanley C.J. et al. (eds.), Mineral Deposits: Processes to Processing. Rotterdam: Balkema, p. 1097-1100.

Gavrilenko E.V., Pérez B.C., Bolibar R., Garcia Del Amo D. 2006. Emeralds from the Delbegetey deposit (Kazakhstan): mineralogical characteristics and fluid inclusion study. Mineralogical Magazine, 70(2):159-173. https:// doi.org/10.1180/0026461067020321

Giuliani G., Silva L.J.H.D., Couto P. 1990. Origin of emerald deposits of Brazil. Mineralium Deposita, 25(1):57-64. https://doi.org/10.1007/ BF03326384

Graziani G., Gübelin E., Lucchesi S. 1983. The genesis of an emerald from the Kitwe District, Zambia. Neues Jahrbuch für Mineralogie Monatshefte, 4:75-186.
Graziani G., Lucchesi S. 1979. Einschlusse und Genese eines Vanadiumberylis von Salininha/BA, Brasilien. Zeitschrift der Deutsche Gemmologische Gesellschaft, 28(3):134-145.

Groat L.A., Giuliani G., Marshall D.D., Turner D. 2008. Emerald deposits and occurrences: A review. Ore Geology Reviews, 34:87-112.

Groat L.A., Marshall D.D., Giuliani G., Murphy D.C., Piercey S.J., Jambor J.L., Mortensen J.K., Ercit T.S., Gault R.A., Mattey D.P., Schwarz D., Maluski H., Wise M.A., Wengzynowski W., Eaton D.W. 2002. Mineralogical and geochemical study of the Regal Ridge Emerald Showing, Southeastern Ukon. The Canadian Mineralogist, 40(5):1313-1338.

Gübelin E.J. 1958. Emeralds from Sandawana. Journal of Gemmology, 6(8):340-354

Hammarstrom J.M. 1989. Mineral chemistry of emeralds and some minerals from Pakistan and Afghanistan: an electron microprobe study. In: Kazmi A.H., Snee I.W. (eds.), Emeralds of Pakistan: Geology, Gemology and Genesis. New York: Van Nostrand Reinhold, p. 125-150.

Hanni H.A. 1982. A contribution to the separability of natural and synthetic emeralds. Journal of Gemmology, 18(2):138-143.

Hanni H.A., Kerez C.J. 1983. Neues vom Smaragd-Vorkommen von Sta. Terezinha de Goiás, Brasilien. Zeitschrift der Deutschen Gemmologischen Gesellschaft, 32(1):50-58

Hanni H.A., Klein H.H. 1982. Ein Smaragdvorkommen in Madagaskar. Zeitschrift der Deutschen Gemmologischen Gesellschaft, 21:71-77.

Hanni H.A., Schwarz D., Fishcer M. 1987. Die Smaragde der Belmont Mine bei Itabira, Minas Gerais, Brasilien; Vorkommen und Charakteristika. Zeitschrift der Deutschen Gemmologischen Gesellschaft, 36(1-2):33-49.

Jochum K.P., Weis U., Stoll B., Kuzmin D., Yang Q. Raczek I., Jacob D.E., Stracke A., Birbaum K., Frick D.A., Günther D., Enzweiler J. 2011. Determination of reference values for NIST SRM 610-617 glasses following ISO guidelines. Geostandards and Geoanalytical Research, 35(4):397-429. https://doi.org/10.1111/j.1751-908X.2011.00120.x

Kovaloff P. 1928. Geologist's report on Somerset emeralds. South African Mining and Engineering Journal, 39:101-103.

Kozlowski A., Metz P., Estrada Jaramillo H.A. 1988. Emeralds from Somondoco, Colombia: chemical composition, fluid inclusions and origin. Neues Jahrbuch für Mineralogie - Abhandlungen, 159(1):23-49.

Leitmeier H. 1937. Das Smaragdvorkommen in Habachtal in Salzburg und seine Mineralien. Tschermak's Mineralogische und Petrographische Mitteilungen, 49:245-368.

Malvern Panalytical. 2018. ASD FieldSpec 4 Standard-Res Spectroradiometer. Available at: <https://www.asdi.com/products-and-services/fieldspecspectroradiometers/fieldspec-4-standard-res/>. Accessed on: Jan. 29, 2019.

Marshall D.D., Downes P.J., Ellis S., Greene R., Loughrey L., Jones P. 2016. Pressure-temperature-fluid constraints for the Poona emerald deposits, Western Australia: fluid Inclusion and stable isotope studies. Minerals, 6(4):130-152. https://doi.org/10.3390/min6040130

Marshall D.D., Groat L.A., Falck H., Giuliani G., Neufeld H.L.D. 2004. The Lened emerald prospect, Northwest Territories, Canada: insights from fluid inclusions and stable isotopes, with implications for northern Cordilleran emerald. Canadian Mineralogist, 42(5):1523-1539. https://doi. org/10.2113/gscanmin.42.5.1523

Martin H.J. 1962. Some observations on southern Rhodesian emeralds and chrysoberyls. Journal of the Chamber of Mines, 4(10):34-38.

Medeiros V.C. (ed.). 2008. Geologia e Recursos Minerais da Folha Sousa SB.24-Z-A. Escala 1:250.000. Recife: CPRM - Serviço Geológico do Brasil, $312 \mathrm{p}$.

Moraes J.F.S. 1999. Gemas do Estado do Rio Grande do Norte. Recife: CPRM - Serviço Geológico do Brasil, 72 p.

Otero Muñoz G., Barriga Villalba A.M. 1948. Esmeraldas de Colombia. Bogota: Banco de la Republica, 133 p.

Ottaway T.L. 1991. The Geochemistry of the Muzo Emerald Deposit, Colombia. MS Dissertation, University of Toronto, Toronto, $216 \mathrm{p}$. 
Petrusenko S., Arnaudov V., Kostov I. 1966. Emerald pegmatite from the Urdini Lakes, Rila Mountains. Annuaire de l'Université de Sofia, 59:247-268.

Rondeau B., Fritsch E., Peucat J., Nordrum F.S., Groat L. 2008. Characterization of Emeralds from a historical deposit: Byrud (Eidsvoll), Norway. Gems and Gemology, 44(2):108-122. https://doi.org/10.5741/ GEMS.44.2.108

Santiago J.S., Souza V.S., Filgueiras B.C., Jiménez F.A.C. 2018. Emerald from the Fazenda Bonfim Deposit, northeastern Brazil: chemical, fluid inclusions and oxygen isotope data. Brazilian Journal of Geology, 48(3):457-472.

Santos E.J., Souza Neto J.A., Silva M.R.R., Beurlen H., Cavalcanti J.A.D., Silva M.G., Dias V.M., Costa A.F., Santos L.C.M.L., Santos R.B. 2014. Metalogênese das porções norte e central da Província Borborema. In: Silva M.G., Rocha Neto M.B., Jost H., Kuyumijan R.M. (eds.), Metalogênese das províncias tectônicas brasileiras. Belo Horizonte: CPRM, p. 343-388.

Schmetzer K., Berdesinski W., Bank H. 1974. Über die Mineralart Beryll, ihre Farben und Absorptionsspektren. Zeitschr. Gemmologischen Gesellschaft, 23(1):5-39.

Schmetzer K., Kiefert L., Bernhardt H., Beili Z. 1997. Characterization of Chinese hydrotermal synthetic emerald. Gems and Gemology, 33(4):276-291. https://doi.org/10.5741/GEMS.33.4.276

Scholz R., Romano A.W., Belotti F.M., Chaves M.L.S.C. 2010. Geochemical prospecting of beryl emerald variety in the Fazenda Bonfim region (Lajes, RN). Geociências, 29(4):613-621.

Schwarz D. 1987. Esmeraldas: inclusões em gemas. Ouro Preto: Universidade Federal de Ouro Preto (UFOP), Imprensa Universitária, 439 p.

Schwarz D. 1991. Australian emeralds. Australian Gemmologist, 17(12):488-497.

Schwarz D. 1998. The importance of solid and fluid inclusions for the characterization of natural and synthetic emeralds. In: Giard D. (ed.) L'émeraude. France: Association Française de Gemmologie, p. 71-80.

Simpson E.S. 1948. Minerals of Western Australia. Perth Government Printer, 1:195-207.

Souza L.C. (ed.). 2017. Geologia e Recursos Minerais da Folha Pau dos Ferros SB.24-Z-A-II. Escala 1:100.000. Recife: CPRM - Serviço Geológico do Brasil / Universidade Federal do Rio Grande do Norte, 109 p.

Vapnik Y., Moroz I., Roth M., Eliezri I. 2006. Formation of emeralds at pegmatite-ultramafic contacts based on fluid inclusions in Kianjavato emerald, Mananjary deposits, Madagascar. Mineralogical Magazine, 70(2):141-158. https://doi.org/10.1180/0026461067020320

Vapnik Y., Sabot B., Moroz I. 2005. Fluid inclusions in Ianapera emerald, Southern Madagascar. International Geology Reviews, 47(6):647-662. https://doi.org/10.2747/0020-6814.47.6.647

Vasconcelos F.J.C. 1984. Ocorrência de esmeralda em Pitombeiras, município de Paraná, Estado do Rio Grande do Norte. Especialização em Gemologia, Instituto de Geociências, Universidade Federal de Minas Gerais, Belo Horizonte, $36 \mathrm{p}$.

Viegas L.G.F., Archanjo C.J., Hollanda M.H.B.M., Vauchez A. 2014 Microfabrics and zircon U-Pb (SHRIMP) chronology of mylonites from the Patos shear zone (Borborema Province, NE Brazil). Precambrian Research, 243:1-17. http://dx.doi.org/10.1016/j.precamres.2013.12.020

Vlasov K.A., Kutakova E.I. 1960. Izumrudnye Kopi. Moscow: Moscow Akademiya Nauk SSGR, $252 \mathrm{p}$

Walton L. 2004. Exploration criteria for coloured gemstone deposits in the Yukon. Yukon: Yukon Geological Survey, 184 p.

Webster R. 1975. Gems, their sources, descriptions and identification. $3^{\text {a }} \mathrm{ed}$. London: Butterworth and Co. Publishers, $938 \mathrm{p}$.

Wood D.L., Nassau K. 1967. Infrared spectra of foreign molecules in beryl. Journal of Chemical Physics, 47:2220-2228. https://doi. org/10.1063/1.1703295

Wood D.L., Nassau K. 1968. The characterization of beryl and emerald by visible and infrared absorption spectroscopy. The American Mineralogist, 53(5-6):777-800.

Zambonini F., Caglioto V. 1928. Ricerche chimiche sulla rosterite di San Piero in Campo (Isola d'Elba) e sui berilli in generale. Gazzetta Chimica Italiana, 58:131-152.

Zwaan J.C. 2006. Gemmology, geology and origin of the Sandawana emerald deposits, Zimbabwe. Scripta Geologica, 131:1-211.

Zwaan J.C., Jacob D.E., Haeger T., Cavalcanti Neto M.T.O., Kanis J. 2012. Emeralds from the Fazenda Bonfim Region, Rio Grande do Norte, Brazil. Gems and Gemology, 48(1):2-17. http://dx.doi.org/10.5741/GEMS.48.1.2

Zwaan J.C., Seifert A., Vrána S., Laurs B.M., Anckar B., Simmons W.B. Falster A.U., Lustenhouwer W.J., Koivula J.I., Garcia-Guillerminet H. 2005. Emeralds from the Kafubu area, Zambia. Gems and Gemology, 41(2):2-34. https://doi.org/10.5741/GEMS.41.2.116 